\title{
Inflammatory Cascade in Alzheimer's Disease Pathogenesis: A Review of Experimental Findings
}

\author{
Jade de Oliveira ${ }^{1}\left(\right.$, Ewa Kucharska ${ }^{2}$, Michelle Lima Garcez ${ }^{3}$, Matheus Scarpatto Rodrigues ${ }^{1}(\mathbb{D}$, \\ João Quevedo ${ }^{4,5,6,7}$, Ines Moreno-Gonzalez ${ }^{8,9,10} \oplus$ and Josiane Budni ${ }^{11, *(1)}$
}

1 Programa de Pós-Graduação em Ciências Biológicas: Bioquímica, Departamento de Bioquímica, Instituto de Ciências Básicas da Saúde, Universidade Federal do Rio Grande do Sul, Porto Alegre 90050-000, Brazil; deoliveirajade10@gmail.com (J.d.O.); matheus_scarodrigues@hotmail.com (M.S.R.)

2 Faculty of Education, Institute of Educational Sciences, Jesuit University Ignatianum in Krakow, 31-501 Krakow, Poland; ewa.kucharska@vadimed.com.pl

3 Department of Biochemistry, Federal University of Santa Catarina, Florianópolis 88040-900, Santa Catarina, Brazil; garcez.lima.mi@gmail.com

4 Translational Psychiatry Program, Faillace Department of Psychiatry and Behavioral Sciences, McGovern Medical School, The University of Texas Health Science Center at Houston (UTHealth),

Houston, TX 77030, USA; Joao.L.DeQuevedo@uth.tmc.edu

5 Center of Excellence on Mood Disorders, Faillace Department of Psychiatry and Behavioral Sciences, McGovern Medical School, The University of Texas Health Science Center at Houston (UTHealth), Houston, TX 77030, USA

6 Neuroscience Graduate Program, Graduate School of Biomedical Sciences, MD Anderson Cancer Center, UTHealth, The University of Texas Houston, Houston, TX 77030, USA

7 Graduate Program in Health Sciences, Translational Psychiatry Laboratory, University of Southern Santa Catarina (UNESC), Criciuma 88806-000, Brazil

Citation: de Oliveira, J; Kucharska, E.; Garcez, M.L.; Rodrigues, M.S.; Quevedo, J.; Moreno-Gonzalez, I.; Budni, J. Inflammatory Cascade in Alzheimer's Disease Pathogenesis: A Review of Experimental Findings. Cells 2021, 10, 2581. https://doi.org/ 10.3390/cells10102581

Academic Editors: Illana Gozes and Carmen Laura Sayas

Received: 6 August 2021

Accepted: 16 September 2021

Published: 28 September 2021

Publisher's Note: MDPI stays neutral with regard to jurisdictional claims in published maps and institutional affiliations.

8 Department of Cell Biology, Faculty of Sciences, University of Malaga, IBIMA, 29010 Malaga, Spain; inesmoreno@uma.es

9 Networking Research Center on Neurodegenerative Diseases (CIBERNED), 29010 Malaga, Spain

10 Department of Neurology, McGovern Medical School, The University of Texas Health Science Center at Houston (UTHealth), Houston, TX 77030, USA

11 Programa de Pós-Graduação em Ciências da Saúde, Laboratório de Neurologia Experimental, Universidade do Extremo Sul Catarinense, Criciuma 88806-000, Brazil

* Correspondence: josiane.budni@unesc.net; Tel.: +55-48431-2539

Abstract: Alzheimer's disease (AD) is the leading cause of dementia worldwide. Most AD patients develop the disease in late life, named late onset AD (LOAD). Currently, the most recognized explanation for AD pathology is the amyloid cascade hypothesis. It is assumed that amyloid beta $(\mathrm{A} \beta)$ aggregation and deposition are critical pathogenic processes in $\mathrm{AD}$, leading to the formation of amyloid plaques, as well as neurofibrillary tangles, neuronal cell death, synaptic degeneration, and dementia. In LOAD, the causes of $A \beta$ accumulation and neuronal loss are not completely clear. Importantly, the blood-brain barrier (BBB) disruption seems to present an essential role in the induction of neuroinflammation and consequent $\mathrm{AD}$ development. In addition, we propose that the systemic inflammation triggered by conditions like metabolic diseases or infections are causative factors of BBB disruption, coexistent inflammatory cascade and, ultimately, the neurodegeneration observed in AD. In this regard, the use of anti-inflammatory molecules could be an interesting strategy to treat, delay or even halt $\mathrm{AD}$ onset and progression. Herein, we review the inflammatory cascade and underlying mechanisms involved in AD pathogenesis and revise the anti-inflammatory effects of compounds as emerging therapeutic drugs against AD.

Keywords: Alzheimer's disease; neurodegenerative disease; dementia; neuroinflammation; inflammatory cascade; systemic inflammation; BBB disruption; anti-inflammatory effects; therapy 


\section{Introduction}

An estimated 50 million people worldwide have dementia, a number projected to double every 20 years until 2050 [1,2]. The majority of demented individuals develop Alzheimer's disease (AD). Thus, AD represents a tremendous healthcare challenge of the 21 st century [3,4]. The typical clinical presentation of this age-related neurodegenerative disease is a gradual and progressive decline in different cognitive domains, most commonly involving episodic memory and executive functions that cause social and occupational deficits [5].

$\mathrm{AD}$ is characterized by pathological hallmarks such as extracellular amyloid plaques, formed by the deposition of amyloid $\beta$-peptide $(A \beta)$, the appearance of intracellular neurofibrillary tangles, composed of hyperphosphorylated tau and extensive synaptic and neuronal loss in the cerebral cortex and hippocampus [6]. In addition, it has been proposed that neuroinflammation is an early feature of $\mathrm{AD}[7,8]$. Thus far, the amyloid cascade hypothesis is the main influential model to explain the progression of $\mathrm{AD}$ pathogenesis $[9,10]$. However, the field is gradually moving away from the simplistic assumption of linear causality proposed in the original amyloid hypothesis [11,12]. Importantly, it has been shown that tau pathogenesis could be associated with neurodegeneration and neuroinflammation regardless of $A \beta$ pathology $[13,14]$. Moreover, APOE4 is the strongest genetic risk factor for LOAD. The presence of APOE4 is associated with increased A $\beta$ deposition, but also tau pathology [15,16]. In fact, APOE is involved in tau pathogenesis through neuroinflammation processes [17].

$\mathrm{AD}$ can be divided into early-onset $\mathrm{AD}$ (EOAD) and late-onset $\mathrm{AD}$ (LOAD). EOAD is rare, accounting for less than $5 \%$ of the cases [18,19] and its onset occurs before 65 years. Mutations in three genes, which encode amyloid protein precursor (APP), presenilin1 (PSEN1), and presenilin-2 (PSEN2), are known to cause a proportion of autosomal dominant inherent $\mathrm{EOAD}$, or autosomal dominant $\mathrm{AD}(\mathrm{ADAD})$. In the genetic form of $\mathrm{AD}$, $A \beta$ accumulation is due to a significant higher peptide production [20]. The most common form, $\mathrm{LOAD}$, is assumed to be a multifactorial and polygenic disease and, therefore, the etiology of $A \beta$ deposition and neurodegeneration in these cases is unknown [19].

Considering the high epidemiological impact of $\mathrm{AD}$, it is fundamental to understand the mechanisms involved in its pathological onset and advancement. In this regard, inflammation seems to play an essential role in disease development and progression. On one hand, clinical and preclinical studies analyzing brains from individuals with AD or experimental models of $\mathrm{AD}$ provide evidence for the activation of inflammatory pathways. On the other hand, anti-inflammatory compounds are associated with a reduced risk of developing and disease progression [21-23]. During decades, inflammatory processes have been explored in an effort to identify alternative therapeutic targets, alone or in combination with other drugs. In this review, we discuss the most relevant evidences that point out neuroinflammation as a crucial event in AD pathophysiology and its potential as an innovative target to treat $\mathrm{AD}$.

\section{Pathogenic Mechanisms of Alzheimer's Disease}

Until now, amyloid hypothesis has been the most stablished model of AD pathogenesis. It proposes that the deposition of misfolded and aggregated $A \beta$ is a critical and the initial pathological event in $\mathrm{AD}$, triggering synaptic dysfunction, neuronal loss, and cognitive impairment [10,24].

During the amyloidogenic pathway, $\mathrm{A} \beta$, a peptide of $36-43$ amino acids, is generated by cleavage of the transmembrane amyloid precursor protein (APP) through sequential proteolytic processing. In this via, APP is first cleaved by $\beta$-secretase (beta-site amyloid precursor protein-cleaving enzyme 1, BACE-1), producing an extracellular soluble fragment (i.e., s $\beta A P P$ ) and an intracellular C-terminal portion termed C99. Subsequently, the resulting cell-associated C-terminal fragments are subjected to intramembrane proteolysis mediated by $\gamma$-secretase, which generates a spectrum of $\mathrm{A} \beta$ peptides of varied lengths. Concurrently, the non-amyloidogenic APP proteolysis involves cleavage by $\alpha$ - 
and $\gamma$-secretases, resulting in the generation of a long-secreted form of APP (sAPP $\alpha)$ and C-terminal fragments (CTF 83, p3 and AICD50). The APP non-amyloidogenic processing produces non-toxic fragments. The cleavage site for $\alpha$-secretase in APP lies within the $\mathrm{A} \beta$ sequence and thus precludes A $\beta$ formation. Usually, about $90 \%$ of APP enters the non-amyloidogenic pathway, while the rest follows the amyloidogenic via $[25,26]$.

The total $A \beta$ burden is regulated by synthesis and clearance rates. In fact, $A \beta$ clearance or degradation, rather than its synthesis, has been considered critical in $\mathrm{A} \beta$ accumulation. The clearance of the peptide by transport into the cerebrospinal fluid (CSF), the blood across the blood-brain barrier (BBB), and the removal by macrophages have been suggested as the responsible mechanisms for controlling the brain $A \beta$ levels [27]. Furthermore, CSF clearance seems to be impaired in $\mathrm{AD}$, contributing to increase $\mathrm{A} \beta$ burden and disease progression [28]. Some proteases, such as some cathepsins and insulin-degrading enzyme (IDE), play essential roles by cleaving $A \beta$ into shorter soluble fragments without neurotoxic effect [29]. The central receptors for $A \beta$ transport across the BBB from the brain to the bloodstream and from the blood to the brain are low-density lipoprotein receptor (e.g., LRP-1) and the receptor for advanced glycation end products (RAGE), respectively [30]. A chronic imbalance between $\mathrm{A} \beta$ production and clearance may result in the agglomeration of intracellular and extracellular aggregates in the brain.

$\mathrm{A} \beta$ peptides spontaneously aggregate into soluble oligomers, fibrils, and deposit as senile plaques. These events cause toxicity through several mechanisms, including oxidative injury, microglial and astrocytic activation, as well as altering kinase/phosphatase activity, eventually leading to synaptic damage and neuronal death. It is important to mention that $A \beta$ oligomers are the most neurotoxic form $[24,31]$.

Besides the strong evidence about the relation between $A \beta$ and neurodegeneration, there is a continuous debate about the $A \beta$ hypothesis $[10,32]$. This is mainly due to the constant failure of developing disease-modifying drugs targeting $A \beta$, preventing neither its aggregation, accumulation, nor clearance. Nowadays, the Aducanumab efficiency has been extensively discussed, a human IgG1 anti-A $\beta$ monoclonal antibody specific for $A \beta$ oligomers and fibrils [33]. Other reasons are the difficulty correlating the $A \beta$ deposits and $\mathrm{AD}$ pathology and the disconnection between $\mathrm{A} \beta$ and phosphorylated tau deposition. In fact, tau pathology (tauopathy) has been related to neurodegeneration and neuroinflammation independently of $A \beta$. In addition, there are substantial differences between familial and sporadic diseases. Importantly, peripheral inflammatory diseases have been considered risk factors for AD development, which may not be directly associated with the $A \beta$ dyshomeostasis [13,32]. This is a discussion that is far from over. Then, new insights into $\mathrm{AD}$ pathophysiology are driving the development of drugs towards novel therapeutic targets $[34,35]$. In this scenario, the inflammatory process has been evaluated as an important component of $\mathrm{AD}$ pathogenesis. It is well known that $\mathrm{A} \beta$ causes neuroinflammation, and many studies have demonstrated the role of inflammation in the early stages of $\mathrm{AD}$ development $[36,37]$.

Moreover, the neurofibrillary tangles (NFT), which Alois Alzheimer first described, are another crucial hallmark of AD pathogenesis [38-40]. In this case, the tau protein is aberrantly misfolded and abnormally hyperphosphorylated [40,41]. Tau protein regulates the assembly and stabilization of microtubules. It can be expressed in neurons and oligodendrocytes [42-46].

In $A D$, the NFT could appear after $A \beta$ accumulation. Considering that plaqueassociated dystrophic neurites are not associated with tau, it is probably true that $A \beta$ mediated neuritic dystrophy occurs first, and the tau accumulation is a consequence of this [47-49]. Furthermore, a study conducted by Hurtado et al. [50] showed that $A \beta$ accelerated NFT formation and enhanced tau amyloidosis. Thus, it seems in AD that A $\beta$ plaque deposition drives cortical tau pathology and tau-mediated neurodegeneration [51,52]. In $\mathrm{AD}$ neurodegeneration, $\mathrm{A} \beta$ diffuse deposits, non-neuritic plaques occur first. Then, the microglia are activated by $\mathrm{A} \beta$ deposits, inducing dystrophic neurites that lack tau. This leads to the aggregation of tau hyperphosphorylated facilitating the spread of tau from the 
limbic system to the cerebral neocortex. The tau hyperphosphorylated distributes from the plaque-associated dystrophic neurites forming NFT throughout the neuron, causing neuronal damage and dementia [53-57].

These events showed the relationship between $A \beta$ and tau, mediated by microglia, causing neurodegeneration and the consequent development of dementia [56].

\section{Inflammatory Cascade in Alzheimer's Disease}

The innate immune system is the first line of defense against pathogens [58]. The microglia have a fundamental role in early response to central nervous system (CNS) alterations such as damage or infection, development, and homeostasis [59]. Microglia activation is an important event during aging and in neurodegenerative diseases. These cells participate in neuroinflammatory events directly via phagocytosis and cytokine production, as shown by identifying disease-specific microglia, or indirectly responding to cues from the adaptive immune system $[60,61]$.

Neuroinflammation plays a crucial role in the pathogenesis of AD. Several studies have reported the presence of inflammatory markers in the brain of patients, including elevated levels of cytokines/chemokines in serum and CSF, along to microgliosis [62-66]. The increase in these molecules is positively correlated to the cognitive impairment at different stages of $\mathrm{AD}$ as well as in individuals with mild cognitive impairment (MCI) [67-69].

Recent genome-wide association studies have shown that most polymorphisms recently found in $\mathrm{AD}$ patients are involved in the immune response and microglial function. For instance, complement receptor 1 (CR1), CD33, membrane-spanning 4A (MS4A), clusterin (CLU), ATP-binding cassette sub-family A member 7 (ABCA7), sortilin-related receptor 1 (SORL1), inositol polyphosphate-5-phosphatase D (INPP5D), and triggering receptor expressed on myeloid cells 1 and 2 (TREM1, TREM2) [70,71]. Among them, the most prominent polymorphism was found in TREM2, which is associated with phagocytosis [72].

Several studies have shown that $\mathrm{A} \beta$ can activate microglia and inflammatory cytokines production [73-75]. Even in the prodromal stages of $A D, A \beta$ soluble oligomers can impair synaptic plasticity, inhibit long-term potentiation, and activate microglia [10]. The intracerebral administration of $A \beta$ causes neuroinflammation and memory impairment even in normal adult rodents $[74,76,77]$. In addition, neuroinflammation and proinflammatory cytokines increase tau phosphorylation and decrease synaptophysin levels, which leads to cytoskeletal instability and neuronal death [78].

The activation of the immune system in the brain occurs through microglial activation of pattern recognition receptors (PRRs), which identify potentially harmful molecules, activating the innate immune system [79]. Several studies have shown that $A \beta$ species can activate PRRs, consequently triggering an immune response [74,80-83].

$A \beta$ activates several microglial receptors, such as CD36, a class B scavenger receptor, causing secretion of cytokines, chemokines, and reactive oxygen species [84]. Its binding to RAGE induces inflammatory pathways and increases expression of proinflammatory cytokines, such as TNF $\alpha$ and IL-6 [85]. However, the best described pathway is through the activation of Toll-like receptors (TLRs), including TLR2, TLR4, and TLR6 and TREM2 $[86,87]$. The TLR pathway is responsible for the maturation and release of IL- $1 \beta$, one of the main pro-inflammatory cytokines involved in the pathophysiology of $\mathrm{AD}$. In fact, IL-1 $\beta$ polymorphism is correlated with the age at $\mathrm{AD}$ onset in humans, whereas inhibition of its receptor recues cognitive impairment in animal models [88,89]. IL- $1 \beta$ is produced as a precursor, pro-IL-1 $\beta$, and requires cleavage to become biologically active. To this end, the pro-IL- $1 \beta$ is cleaved by a complex of intracellular proteins that form the nucleotidebinding oligomerization domain-like receptor family pyrin domain containing 3, known as the NLRP3 inflammasome [90,91]. For NLRP3 assembly, two signals are needed. The first one is the activation of TLRs by $A \beta$ or another potentially harmful molecule. After TLR activation, the signal is transduced through myeloid primary response protein 88 (MyD88), activating nuclear factor kappa B (NF-kB), which leads to transcription of NLRP3 components and proinflammatory cytokines, mainly IL- $1 \beta$. The second signal is triggered 
by damage-associated molecular patterns (DAMPs), such as heat shock proteins or ATP, released after cell death. It was proposed by Heneka and col. that this second signal also occurs through phagocytosis of $A \beta$ fragments via TREM2 [90].

The $A \beta$ overload leads to a deficient lysosome degradation of the $A \beta$ fragments, leading to lysosome disruption, cathepsin B release, and the induction of NLRP3 inflammasome assembly $[90,92,93]$. The inflammasome complex assembly includes the NLRP3 protein, the adapter apoptosis-associated speck-like protein containing a CARD (ASC), and the effector caspase-1. After the NLRP3 complex assembles, caspase- 1 cleaves the pro-IL-1 $\beta$ and pro-IL-18, generating the mature form of these cytokines, which activate neutrophils, macrophages, and other microglial cells, amplifying the response inflammatory [94], as represented in Figure 1. This inflammatory pathway has been increasingly described in different neurodegenerative diseases $[75,90,91,95,96]$.

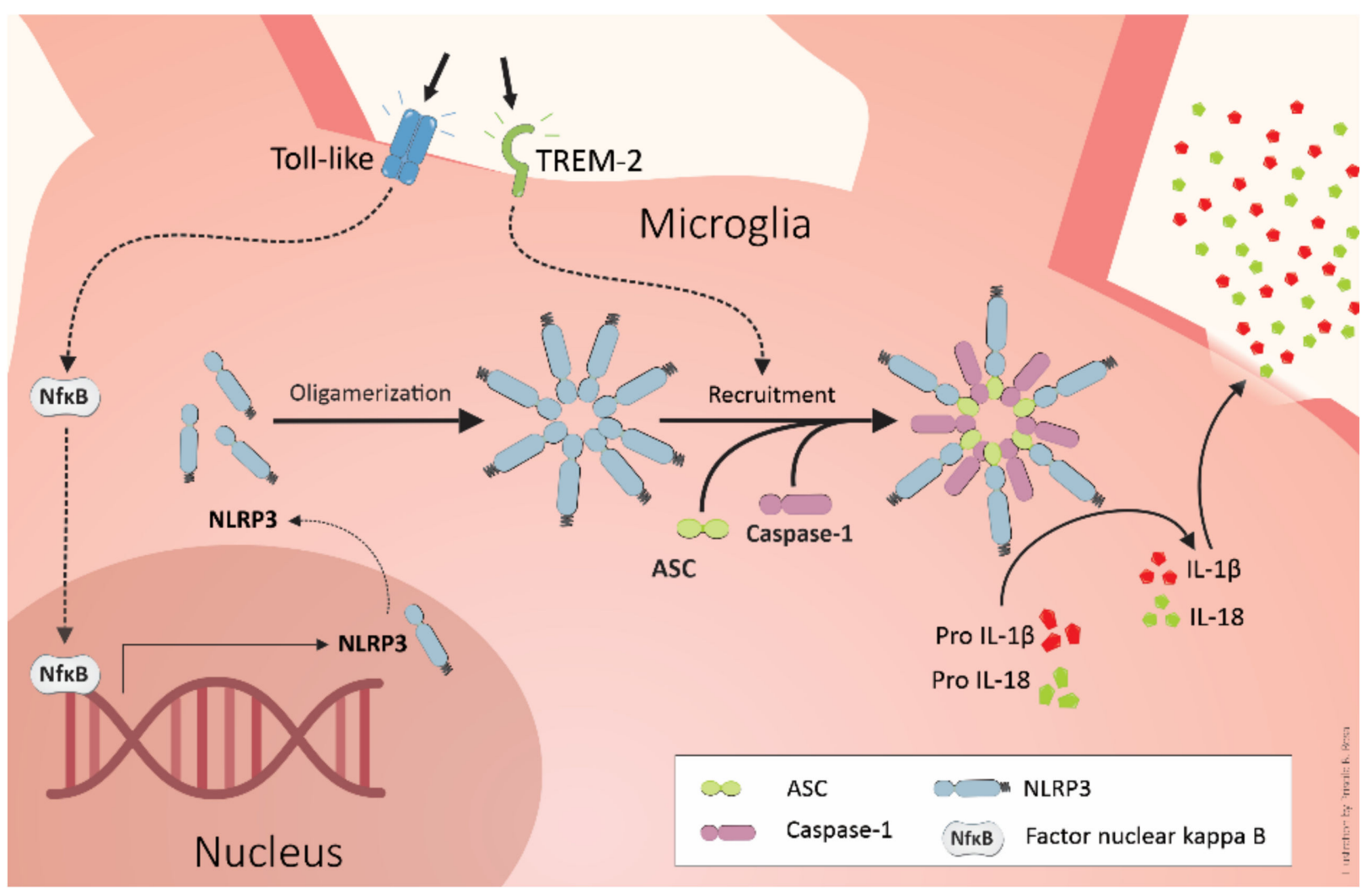

Figure 1. The activation of Toll-like receptors by ligands such as LPS or A $\beta$ species can trigger the first signal for assembly of the NLRP3 inflammasome through nuclear factor kappa B (NF-kB). The second signal can be triggered after A $\beta$-mediated phagocytosis by TREM2. The A $\beta$ overload causes lysosome disruption, releasing cathepsin $\mathrm{B}$, which induces the signal for assembly of NLRP3. The inflammasome contains caspase- 1 that cleaves pro-IL-1 $\beta$ and pro-IL-18, generating the mature forms of these inflammatory cytokines. IL-1 $\beta$ and IL-18, in turn, activate neutrophils, macrophages, and other microglial cells, amplifying the inflammatory response.

The inflammasome activation finally causes cell death by apoptosis and pyroptosis. Pyroptosis is a form of cell death less organized than apoptosis, triggered by inflammation, as Gasdermin-D-mediated pore formation occurs in the membrane and osmotic lysis, with extravasation of intracellular content [97]. When the NLRP3 inflammasome disassembles, its ASC particles are released from the protein complex, which can activate neighboring microglia, perpetuating the immune response. These particles can also bind to $A \beta$, contributing to its aggregation [98]. Thus, the efficient degradation of the inflammasome components is a critical step to limit the inflammatory response. 
The mechanisms of microglial activation by $\mathrm{A} \beta$ depositions have remained not fully elucidated. However, the mechanism known is illustrated in Figure 1. Moreover, A $\beta$ induces the secretion of a variety of additional inflammatory molecules. These molecules include members of the minor compounds of the COX metabolism (prostaglandins), shortlived molecules like nitric oxide (NO), and chemokines [90,99-103].

\section{TREM2 and Alzheimer's Pathogenesis}

The interest in TREM2 increased after the identification of TREM2 variants as risk factors for AD [104,105]. Individuals bearing the heterozygous mutation (rs75932628) in exon 2 of TREM2, a single nucleotide polymorphism that changes arginine to histidine at position $47(\mathrm{R} 47 \mathrm{H})$, produce a four-fold increase in the risk of developing AD [105]. This polymorphism has been validated in neuropathology-confirmed cases and has been shown to increase the risk of sporadic AD as significantly as the ApoE $\varepsilon 4$ allele [106]. TREM2 polymorphism causes structural changes in the receptor, leading to a partial loss of its function. However, the role of TREM2 in neurodegeneration and AD remains unclear [107].

TREM2 is a single-pass transmembrane protein whose ligand-binding domain includes an extracellular immunoglobulin-like domain, anchoring the protein to the membrane and contains the intramembranous lysine residue necessary for association with its intracellular membrane adaptor, DAP12. The binding of agonists to TREM2 through the DAP12 protein recruits the cytosolic spleen tyrosine kinase (Syk), which, in turn, activates signaling components including, phosphatidylinositol 3-kinase (PI3K), Akt, mitogenactivated protein kinases (MAPK), and increases intracellular calcium levels. Thus, its activation exerts functions such as cell maturation, survival, proliferation, phagocytosis, and inflammatory regulation [108]. TREM2 ligands include bacteria, bacterial cell components such as lipopolysaccharide (LPS), lipoproteins, such as apolipoprotein A (ApoA), ApoB, ApoE, low-density lipoprotein (LDL), DNA, HSP60 chaperone protein, and A $\beta$ [109].

TREM2 expressed on the cell surface can also undergo proteolysis by $\alpha$-secretase and $\gamma$-secretase [110] to generate soluble TREM2 (sTREM2). The catalytically active components of the $\gamma$-secretase complex are PSEN 1 and 2, the same proteins mutated in familial AD and responsible for $A \beta$ processing. Inhibition of $\gamma$-secretase leads to accumulation of TREM2 c-terminal fragments (CTFs) on the cell surface, impairing signaling and interfering with normal receptor function [111]. This relationship between TREM and PSEN provides evidence about a functional connection between genetic factors found in AD patients.

One of the main mechanisms of TREM2 is undoubtedly its phagocytic activity. In addition, TREM2 expression increases myeloid cell number in response to inflammation or disease [45], besides regulating the inflammatory responses and the clearance of apoptotic neurons and $A \beta$. However, it may depend on the activating by ligand and the availability of the TREM2 signaling machinery [112]. The AD-associated TREM2 variant, R47H, reduces receptor binding capacity and, consequently, decreases $\mathrm{A} \beta$ phagocytosis [113].

In AD patients, microglial cells have decreased phagocytic capacity and a pro-inflammatory phenotype and morphology $[114,115]$. Therefore, amyloidosis levels can be altered since phagocytosis is one of the principal mechanisms for $A \beta$ clearance. The increase in the microglial TREM2 expression reduces $A \beta 1-42$ soluble and insoluble forms, the formation of senile plaques, and improves cognitive impairment in AD transgenic mice [116]. Conversely, TREM2 deficiency seems to interrupt the formation of the neuroprotective barrier composed of microglia around the amyloid plaques, responsible for their isolation, increasing neuronal toxicity [117]. However, $A \beta$ overload can cause phagocytosis disruption, cathepsin B release, and NLRP3 assembly, which leads to the amplification of the inflammatory response. 
Thus, it is controversial whether phagocytosis and inflammation in AD are beneficial or harmful. Perhaps, in the early stages of the disease, the activation of the immune system and induction of phagocytosis can contribute to $\mathrm{A} \beta$ clearance, preventing its toxicity and formation of amyloid deposits. However, chronic inflammation can become detrimental because, if the amyloid load cannot be resolved, it can contribute to the progression of AD [118]. This possible dual role of inflammation in AD progression can be related to microglial function. The microglia are important to scavenging duties. However, it produces reactive oxygen species, secretion of proinflammatory cytokines, or degradation of neuroprotective retinoids when activated. In this case, it may thus unnecessarily put surrounding healthy neurons in danger [119]. Then, the microglia are essential during development and homeostasis, performing critical roles in synaptogenesis and synaptic plasticity. However, in aging and AD, the microglial function is altered, leading the detrimental inflammatory environment [120].

\section{BBB as a Target of Systemic Inflammation: Importance to Alzheimer's Disease Development}

In the brain, BBB blood vessels present particular properties. BBB essentially regulates the passage of substances and cells between blood and the CNS [121]. Several cell types interact to form and support the BBB, which is now referred to as the "neurovascular unit (NVU)" and is composed of the cerebral endothelial cells, basal lamina, astrocytic foot processes, microglia, and pericytes [122].

BBB disruption is closely associated with several neurological diseases [123]. Evidence has pointed out the alteration of BBB as a trigger to AD pathology [124-127]. Previously, Ujiie and col. observed that BBB permeability is higher in a 10-month-old transgenic mouse model of $\mathrm{AD}$ than in age-matched non-transgenic animals [128]. In fact, the impairment in the $\mathrm{BBB}$ is already evident in the AD mouse model at 4 months of age. The BBB leakage seems to occur even before the $A \beta$ deposition and the appearance of other pathological hallmarks of the disease [128]. Corroborating the experimental data, the increased BBB permeability has been demonstrated in early AD individuals [129]. Plasma proteins such as immunoglobulin G (IgG), fibrinogen, and albumin, normally unable to pass the BBB, have been detected around senile plaques in the brain of AD patients [130-132]. The presence of peptides derived from hemoglobin and prothrombin in AD brains has been associated with increased leakage of blood. Prothrombin is not produced by the normal brain but shows increased levels in AD brains consistent with leakage across a disrupted BBB [133].

Another important point is that $\mathrm{BBB}$ is vital to regulate the brain $\mathrm{A} \beta$ metabolism and load, and A $\beta$ deposition could result from an inefficient clearance through BBB $[132,134]$. Firstly, Shibata et al. [135] and other authors pointed out that brain A $\beta$ is mainly cleared across BBB via LRP-1. Importantly, the LRP-1 content is down-regulated in AD brain [132,135-137]. After that, the function of other transporters in the $A \beta$ clearance and AD pathogenesis have been studied, such as RAGE $[132,134,138]$. On the other hand, $\mathrm{A} \beta$ deposition appears to cause BBB damage but is not well evidenced [134]. In addition, it has been demonstrated that BBB endothelial cells respond to truncated tau fragments, ultimately resulting in BBB disruption $[139,140]$

In parallel, other research groups demonstrated the presence and accumulation of peripheral immune cells and increase in pro-inflammatory cytokines, such as IL- $1 \beta$, in AD patient's brain [21,141-144]. The constituents of innate immunity seem to participate in many processes of the underlying pathological cascade in AD. In addition, compiling studies show that innate immunity is involved in the etiology of LOAD [145,146]. In this regard, increased peripheral inflammation levels can be detected in the early stages of AD [147]. A meta-analysis showed that the blood concentrations of several pro-inflammatory mediators, such as IL-6 and IL-1 $\beta$, are increased in AD patients [62,148]. In line with this, previous studies showed that inflammatory mediators' levels are enhanced in the plasma of AD patients 5 years before the clinical onset of dementia compared with age-matched individuals $[149,150]$. However, it is not well established yet whether brain inflammation in $\mathrm{AD}$ subjects is a cause or a consequence of the disease. Although it was previously 
thought that the CNS was an immune-privileged site, it is now admitted that inflammatory processes occur in response to an injury, infection, or disease and the peripheral immune system can infiltrate into the brain to mediate this response [151,152]. Indeed, the systemic inflammation seems to be the causative factor of BBB disruption and, consequently, neurodegeneration and cognitive dysfunction [153-156]. Although still debatable, evidence suggests that early or lifelong systemic inflammation triggers long-lasting modulation of CNS immune responses leading to AD development in late life [157].

\section{Systemic Inflammatory Diseases and the Connection with Alzheimer's Disease Development}

The etiology of sporadic AD is complex and associated with several genetic and behavioral risk factors, in addition to aging [19]. Some of these risk factors related to AD are peripheral diseases, for example, metabolic disorders, such as hypercholesterolemia, diabetes, obesity, and hypertension [158-160]. One possible common event between systemic and brain diseases is chronic systemic inflammation [161]. In line with this, an essential feature of the metabolic disorder's physiopathology is the increased production of pro-inflammatory cytokines [162].

The inflammatory response of the peripheral adipose tissue is an important event of diabetes and obesity [163]. In obese individuals, adipocytes, and resident immune cells of adipose tissue, especially lymphocytes and macrophages, contribute to the increased levels of circulating cytokines, such as TNF- $\alpha$, IL-6, and IL- $1 \beta$, as well as $C$ reactive protein (CRP) [164]. Nowadays, white adipose tissue (WAT) is known to be a secretory tissue, which seems crucial in brain dysfunction development [165]. In hyperglycemia conditions, the NF- $\mathrm{KB}$ - a transcription factor that regulates the induction of several inflammatory genes-is rapidly and strongly activated in vascular cells, resulting in enhanced leukocytes adhesion and pro-inflammatory cytokines transcription [166]. Hyperlipidemias, primarily hypercholesterolemia and hypertriglyceridemia, are also related to systemic inflammation. For instance, the study of Lohmann et al. [167] demonstrated that mice fed with a high cholesterol diet presented generalized inflammation, characterized by increased in $\mathrm{T}$ lymphocytes and macrophage recruitment in adipose tissue, inducing cytokine production [167].

Most of these metabolic risk factors are associated with BBB leakage and neuroinflammation. An epidemiological study showed that overweight or obesity in middle-aged individuals is associated with loss of BBB integrity several years later [168]. Diabetes is usually associated with macro- and microvascular complications, including CNS alterations that result, at least in part, in BBB damage. Impairment of the cerebral microvascular structure, characterized by reduction in capillary density and tight junctions damage, is a relevant mechanism of BBB dysfunction induced by diabetes [169]. Our group have recently demonstrated that hypercholesterolemic mice present high BBB permeability in the hippocampus, associated with intense astrogliosis [170,171].

According to experimental and clinical studies, the BBB is altered in hypercholesterolemia, resulting in the infiltration of immune cells in the brain parenchyma and consequently the production of inflammatory mediators [172-174]. On one hand, this inflammatory response, associated with persistent activation of glial cells, induces neuronal damage and, ultimately, leads to cognitive dysfunction and dementia $[170,171,175]$. On the other hand, when the BBB is damaged, the transport of $A \beta$ is defective. RAGE is overexpressed and the expression of LRPs decreases, leading to the accumulation of $A \beta$ in the brain $[174,176]$. 
In obese individuals, there is a chronic systemic inflammation that induces production of pro-inflammatory cytokines, such as IL-6, and adipokines (such as TNF- $\alpha$ ), mainly produced by WAT. These inflammatory molecules could cause alterations in BBB permeability and, consequently, brain inflammation and neurodegeneration. Deregulation of these molecules could link obesity and AD development [165]. The effects of saturated fatty acids (e.g., palmitic acid) on microglia and astrocyte activation have also been demonstrated. For instance, these fatty acids promote the pro-inflammatory phenotype of microglia, resulting in activation of NF- $\mathrm{kB}$ pathway, TLR-4 receptors, interferon- $\gamma($ IFN- $\gamma)$, and TNF- $\alpha$ production [177].

Metabolic diseases are not the only example of systemic inflammatory pathologies associated with BBB disruption and neurodegeneration. Sepsis is another relevant condition that has been implicated in dysfunction and loss of neurons $[178,179]$. A possible consequence of sepsis is the septic encephalopathy, which occurs in $8-70 \%$ of septic patients. It is related to BBB disruption, leucocyte infiltration, up-regulation of aquaporin-4, activation of microglia, astrocytosis, and neuronal death [178]. This relationship between sepsis and brain alterations is an opportunity to better understand the effects of systemic inflammation in cerebral function [179-181]. In fact, it has been reported that RAGE may be involved in sepsis-mediated increase in amyloidogenic proteins and cognitive impairment [182].

In this context, viral infections associated with intense systemic inflammation have been a concern in the neuroscience field. For instance, COVID-19 could lead to neurodegeneration and increase the risk of $\mathrm{AD}$ due to an intensive brain inflammatory process as a result of systemic inflammation. Furthermore, SARS-CoV-2 (severe acute respiratory syndrome coronavirus 2) is potentially neuroinvasive, suggesting that neurological consequences could occur after direct brain infection [183,184]. Recent studies have reported neurological complications in COVID-19 patients [185-188].

However, it is important to mention that although, growing evidence indicated the relationship between infections and $\mathrm{AD}$, more studies are needed to elucidate better the mechanisms involved. Notably, chronic viral, bacterial, and other infections might be causative factors for the BBB breakdown and coexistent brain inflammatory pathway activation and consequently neurodegeneration $[189,190]$.

Additionally, gut microbiota alterations can cause neuroinflammation and consequently interfere in $\mathrm{AD}$ development. Several reports have pointed out the gut microbiota as a modulator of the neuroinflammatory process in AD [191,192]. Importantly, an imbalance in the gut microbiome is related to systemic inflammation and peripheral conditions like diabetes. Moreover, dietary changes may induce a loss of microbiota ecosystem homeostasis [193,194]. Chronic dysbiosis appears to cause BBB leakage and release of pro-inflammatory molecules, endotoxins, ultimately leading to microglia and astrocytes activation [195]. This scenario also increases intestinal permeability, promoting translocation of bacteria and endotoxins across the epithelial barrier and activation of both enteric neurons and glial cells [191,196]. Moreover, the oral microbiota are also related to AD [197,198]. For instance, periodontitis, the most common chronic oral bacterial infection in adults, is generally caused by Porphyromonas gingivalis [199]. This bacterium has been detected in the brains of AD patients [197], indicating a strong association between periodontal pathogens and AD [198]. Additionally, the reduction in GSK3 $\beta$ activation may help delay the periodontitis-promoted pathological progression of AD [200]. Figure 2 represents some events connecting systemic inflammatory conditions and AD development. 


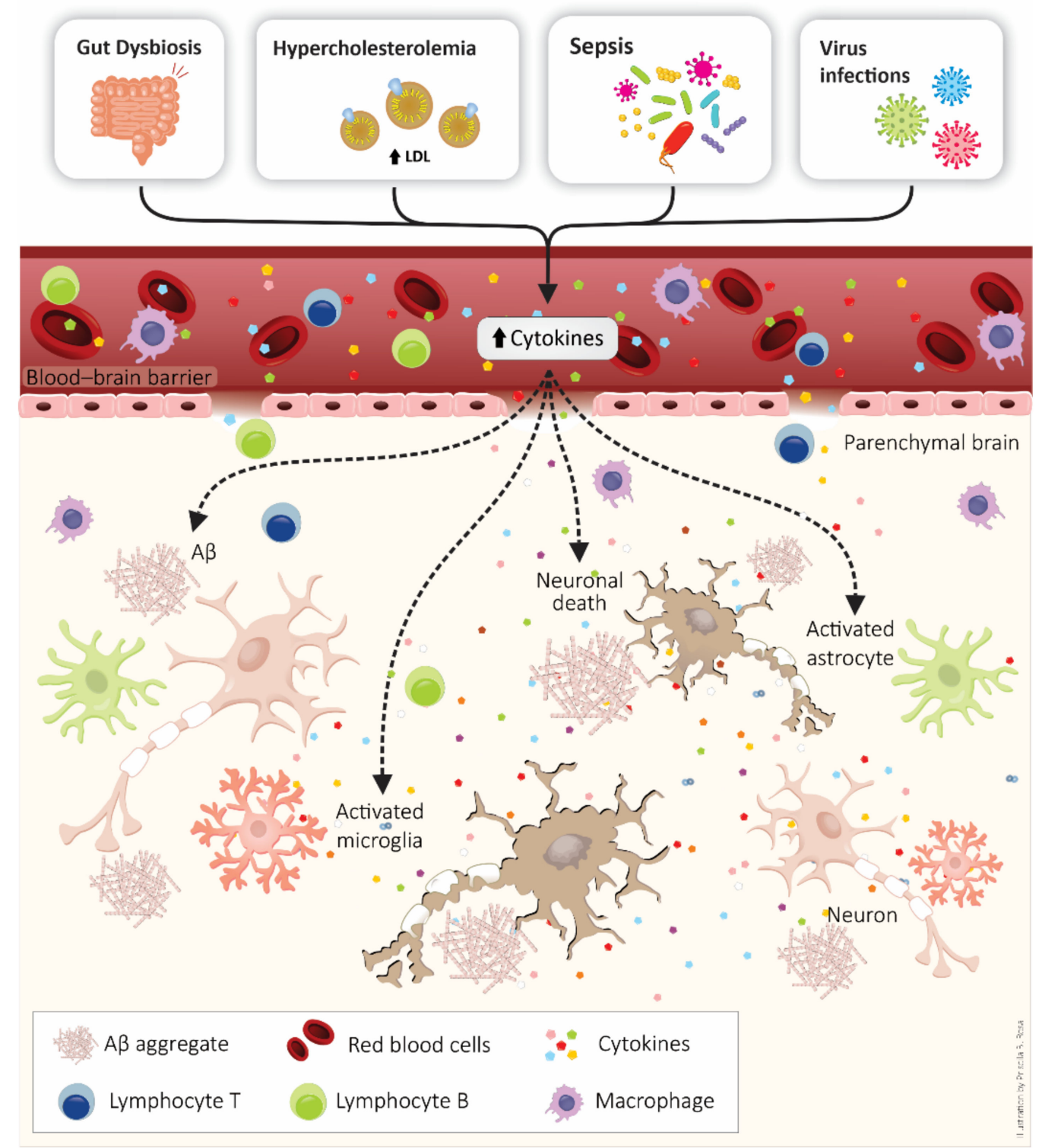

Figure 2. Peripheral diseases are a risk factor for $\beta$-amyloid peptide $(A \beta)$ peptide accumulation, neurodegeneration, and Alzheimer's disease development. Systemic inflammatory conditions, such as metabolic disease, sepsis, virus infections, and dysbiosis, are associated with blood-brain barrier (BBB) disruption and coexistent neuroinflammation. Neuroinflammation is characterized by the presence of the peripheral immune system, activation of glial cells (astrocytes and microglia), and increased production of pro-inflammatory molecules (e.g., cytokines).

\section{Anti-Inflammatory Approaches in the Alzheimer's Disease}

Current approaches for AD management, based on neurotransmission dysfunctions, are not sufficient. These therapies, such as acetylcholinesterase inhibitors and memantine, do not modify the natural course and outcome of the disease. Available treatments are palliative rather than curative or disease-modifying therapies [201]. In this regard, a series of anti-inflammatory drugs have been pointed out as therapeutic strategies to control AD progression [202].

Epidemiological and experimental studies suggest a positive effect of the treatment with non-steroidal anti-inflammatory drugs (NSAIDs) in AD [203-208]. Earlier experimental works indicated that BACE1 expression (mRNA and protein) is stimulated by pro-inflammatory mediators and inhibited by NSAIDs [209,210]. Other studies indicated that treatment with certain NSAIDs decreased brain $A \beta$ accumulation in animal models of 
$\mathrm{AD}$, which was related to anti-inflammatory mechanisms [211-213]. In line with this, in a preclinical study, Medeiros and col. [214] reported that aspirin, the most commonly used NSAID, decreased activation of NF- $\mathrm{KB}$ and generation of pro-inflammatory molecules in $\mathrm{Tg} 2576$ mice. These anti-inflammatory effects caused the activation of phagocytic microglia, resulting in $A \beta$ clearance and improvement of memory. However, these compounds, considered classic anti-inflammatory molecules, have not convincingly shown any beneficial effects during clinical trials in AD patients [215]. In fact, the actions of NSAIDs in dementia depend on the stage of disease progression. Lichtenstein and col. [216] affirmed that the motto for NSAID therapeutics in AD should be "the earlier, the better".

Other studies have examined different anti-inflammatory drugs, e.g., glucocorticoids. Minocycline, for instance, reduces inflammatory parameters in the brain and serum and reverses memory impairment in a mouse model of AD [73]. Specifically, minocycline administration reduces the production of IL- $1 \beta$, TNF- $\alpha$, IL-4, and IL-10 induced by A $\beta 42$ oligomer inoculation in the hippocampus and cortex of mice, which was associated with an improvement in spatial memory. Moreover, the anti-inflammatory effects of minocycline exposure involve TLR2 receptors and NLRP3 [75].

Natural products (e.g., nicotine, vitamin D, vitamin E, melatonin, and resveratrol) also present promising effects in $\mathrm{AD}[217,218]$. Experimental evidence demonstrates antiinflammatory effects and decreased $A \beta$ levels induced by natural compounds [219-223]. For instance, high vitamin D3 diet caused a decrease in amyloid plaques in the brain of APP transgenic mice. The effect of the vitamin D3 supplementation was correlated with diminished levels of TNF- $\alpha$ in the brains of the AD transgenic mouse model [220]. Zhao and col. [221] showed that resveratrol administration in an experimental model of AD (female rats ovariectomized treated with galactose) decreased the NF- $\mathrm{kBp} 65$ and RAGE expression and increased the expression of claudin- 5 in the hippocampus. The control induced by resveratrol exposure on neuroinflammation, and BBB permeability reduced the content of insoluble $A \beta 1-42$ in the hippocampus of the rats. Omega-3 fatty acids (e.g., $\alpha$-linolenic acid) can regulate the microglial activation and control brain inflammation, which seems to prevent AD [177,224,225]. Supplementation with oil fish, containing eicosapentaenoic acid and docosahexaenoic acid, decreased neuroinflammation and improved cognitive impairment in septic aged rats [226].

However, when some anti-inflammatory agents are tested in AD patients, the results are not satisfactory. For instance, Nivaldipine that showed potential anti-inflammatory effects in animals, was not beneficial in treating mild to moderate AD [227]. For cognitively intact individuals, low-dose naproxen does not significantly reduce the progression of presymptomatic $\mathrm{AD}$ [228]. A clinical trial showed that minocycline did not delay cognitive or functional impairment progress in patients with mild AD over 2 years [229]. Other clinical trials performed with aspirin showed no evidence of reducing the risk of dementia, MCI, or cognitive decline [230].

Nanotechnology has also been tested as an anti-inflammatory strategy to treat neuropathologies, particularly in AD [231,232]. Gold nanoparticles treatment prevented neuroinflammation and cognitive impairment in a rat model of sporadic dementia [231]. Rats exposed to streptozotocin, a sporadic AD model, that present memory impairment, increased levels of IL-1 $\beta$ and NF- $\mathrm{kB}$, and showed to improve after gold nanoparticle treatment. Additionally, gold nanoparticle administration ameliorated BBB disruption and brain dysfunction in hypercholesterolemic mice by improving peripheral inflammation [233]. However, more studies are needed, especially to better establish the safety of gold nanoparticle administration. Figure 3 summarizes the main mechanisms of anti-inflammatory drugs and compounds that display anti-inflammatory effects in AD brains. 


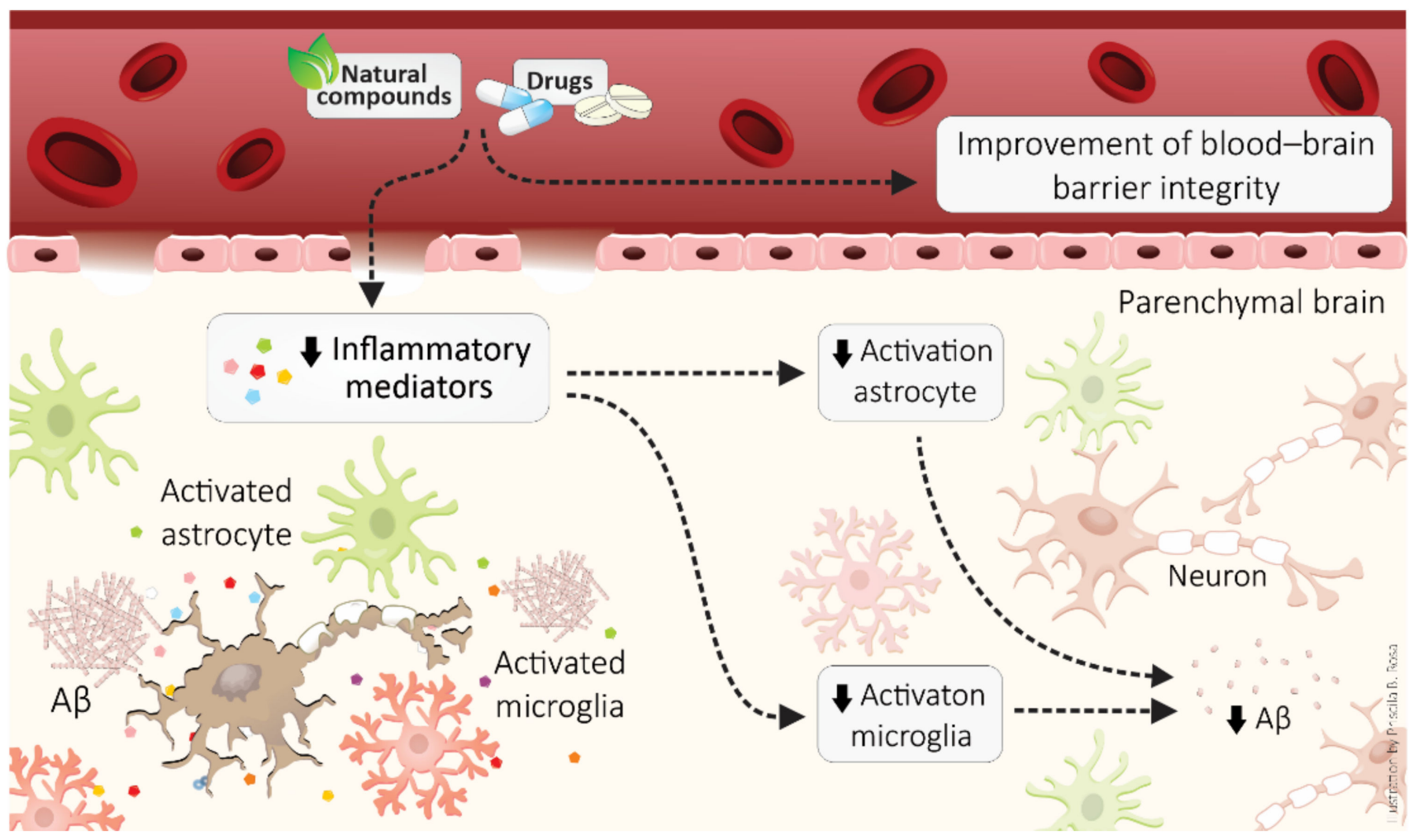

Figure 3. Anti-inflammatory approaches, such as drugs and natural compounds, in Alzheimer's disease. Anti-inflammatory therapeutic strategies improve the blood-brain barrier and neuroinflammation, decreasing activation of astrocytes and microglia as well as generation of pro-inflammatory molecules.

\section{Conclusions}

$\mathrm{AD}$ is a complex, multifactorial, heterogeneous, and severe neurodegenerative disease. It initiates many years before symptoms, as illustrated in Figure 4. Many risk factors are responsible for the development of $\mathrm{AD}$, including genetics, aging, bacteria, diabetes, gut dysbiosis, hypercholesterolemia, obesity, and virus. These risk factors induced systemic inflammation (1) and BBB disruption (2). Thus, $A \beta$ aggregation, tau hyperphosphorylation and, neuroinflammation occur as a possible consequence (3). The neuroinflammation involves the glial activation and release of inflammatory mediators such as NO, IL1- $\beta$, Il-18, TNF- $\alpha$, prostaglandins, and chemokines such as fractalkine (CX3CL1), MIP- $1 \alpha$ (CCI3), IP10 (CXCL10) and, MCP-1 (CCL2). These events lead to neuronal death (4) that culminates in memory loss and changes in mood or personality, featuring dementia-like DA (5). Therefore, anti-inflammatory drugs and compounds that display anti-inflammatory effects in AD brains can be an interesting strategy for AD. Finally, it is essential to mention that due to the existence of many failed pathways involved with AD pathogenesis, the success of anti-inflammatory therapy to treat or prevent AD is still impaired. This phenomenon is exemplified in clinical trials with anti-inflammatory molecules. Therefore, just one anti-inflammatory agent does not have benefit enough in the disease. A combination of therapeutic agents may be needed to have the most significant potential to prevent or treat AD development and/or progression. 


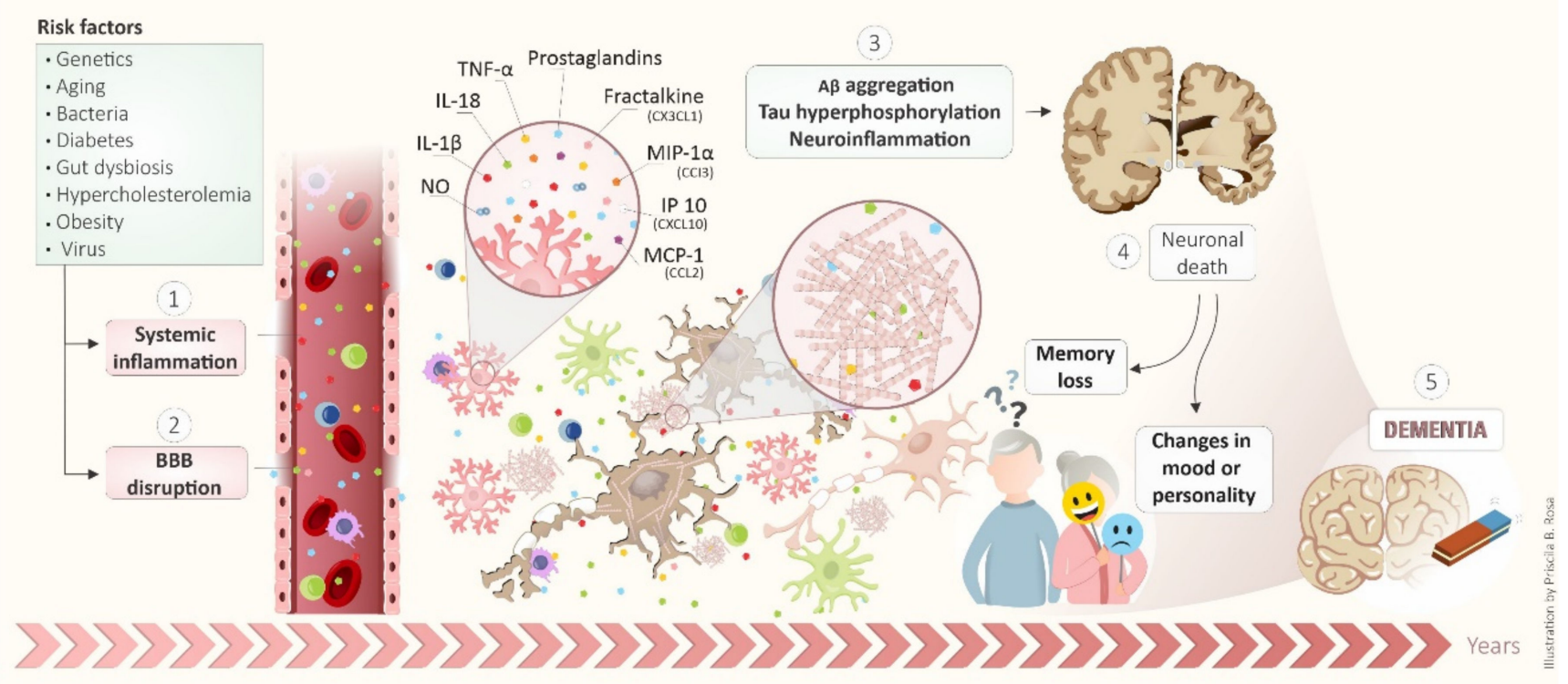

Figure 4. Schematic integrated view of mechanisms involved in development and progression of AD.

Funding: This research received no external funding.

Institutional Review Board Statement: Not applicable.

Informed Consent Statement: Not applicable.

Acknowledgments: The Laboratory of Experimental Neurology (Brazil) is funded by grants from Conselho Nacional de Desenvolvimento Científico e Tecnológico (CNPq), Coordenação de Aperfeiçoamento de Pessoal de Nível Superior (CAPES), Fundação de Amparo à Pesquisa e Inovação do Estado de Santa Catarina (FAPESC), Instituto Cérebro e Mente, UNESC and award "Para Mulheres na Ciência" performed by L'Oréal Brasil, Unesco (Organização das Nações Unidas para a Educação, a Ciência e a Cultura) Brazil e ABC (Academia Brasileira de Ciências). J.O. is funded by Fundação de Amparto do Estado do Rio Grande do Sul (FAPERGS) and Brazilian National Institute of Science and Technology in Excitotoxicity and Neuroprotection (465671/2014-4). J Translational Psychiatry Program (USA) is funded by a grant from the National Institute of Health/National Institute of Mental Health (1R21MH117636-01A1, to JQ) and a research suplement form the Faillace Department of Psychiatry and Behavioral Sciences. Center of Excellence on Mood Disorders (USA) is funded by the Pat Rutherford Jr. Chair in Psychiatry, John S. Dunn Foundation and Anne and Don Fizer Foundation Endowment for Depression Research. Translational Psychiatry Laboratory (Brazil) is funded by grants from Conselho Nacional de Desenvolvimento Científico e Tecnológico (CNPq), Coordenação de Aperfeiçoamento de Pessoal de Nível Superior (CAPES), Fundação de Amparo à Pesquisa e Inovação do Estado de Santa Catarina (FAPESC), and Instituto Cérebro e Mente. J.Q. and J.B. are CNPq Research Fellows. Spanish Ministry of Science and Innovation grant PID2019107090RA-I00, Ramon y Cajal Program RYC-2017-21879, University of Malaga B-2019_06 grant, and NASARD grant 275652018 (IMG).

Conflicts of Interest: J.Q. received clinical research support from LivaNova; has speaker bureau membership with Myriad Neuroscience, Janssen Pharmaceuticals, and Abbvie; is consultant for Eurofarma; is stockholder at Instituto de Neurociencias Joao Quevedo; and receives copyrights from Artmed Editora, Artmed Panamericana, and Elsevier/Academic Press. The other authors declare no conflict of interest.

\section{References}

1. Ijaopo, E.O. Dementia-Related Agitation: A Review of Non-Pharmacological Interventions and Analysis of Risks and Benefits of Pharmacotherapy. Transl. Psychiatry 2017, 7, e1250. [CrossRef]

2. Dementia Statistics I Alzheimer's Disease International (ADI). Available online: https://www.alzint.org/about/dementia-factsfigures/dementia-statistics/ (accessed on 3 August 2021). 
3. McKhann, G.M.; Knopman, D.S.; Chertkow, H.; Hyman, B.T.; Jack, C.R., Jr.; Kawas, C.H.; Klunk, W.E.; Koroshetz, W.J.; Manly, J.J.; Mayeux, R. The Diagnosis of Dementia Due to Alzheimer's Disease: Recommendations from the National Institute on AgingAlzheimer's Association Workgroups on Diagnostic Guidelines for Alzheimer's Disease. Alzheimer's Dement. 2011, 7, $263-269$. [CrossRef]

4. 2020 Alzheimer's Disease Facts and Figures. Alzheimer's Dement. 2020, 16, 391-460. [CrossRef] [PubMed]

5. Tarawneh, R.; Holtzman, D.M. The Clinical Problem of Symptomatic Alzheimer Disease and Mild Cognitive Impairment. Cold Spring Harb. Perspect. Med. 2012, 2, a006148. [CrossRef] [PubMed]

6. Murphy, M.P.; LeVine, H., III. Alzheimer's disease and the amyloid- $\beta$ peptide. J. Alzheimer's Dis. 2010, 19, 311. [CrossRef] [PubMed]

7. Hensley, K. Neuroinflammation in Alzheimer's Disease: Mechanisms, Pathologic Consequences, and Potential for Therapeutic Manipulation. J. Alzheimer's Dis. 2010, 21, 1-14. [CrossRef]

8. Latta, C.H.; Brothers, H.M.; Wilcock, D.M. Neuroinflammation in Alzheimer's Disease; a Source of Heterogeneity and Target for Personalized Therapy. Neuroscience 2015, 302, 103-111. [CrossRef]

9. Hardy, J.A.; Higgins, G.A. Alzheimer's Disease: The Amyloid Cascade Hypothesis. Science 1992, 256, 184-186. [CrossRef]

10. Selkoe, D.J.; Hardy, J. The Amyloid Hypothesis of Alzheimer's Disease at 25 Years. EMBO Mol. Med. 2016, 8, 595-608. [CrossRef]

11. Canevelli, M.; Bruno, G.; Cesari, M. The Sterile Controversy on the Amyloid Cascade Hypothesis. Neurosci. Biobehav. Rev. 2017, 83, 472-473. [CrossRef]

12. Ricciarelli, R.; Fedele, E. The Amyloid Cascade Hypothesis in Alzheimer's Disease: It's Time to Change Our Mind. Curr. Neuropharmacol. 2017, 15, 926-935. [CrossRef]

13. Laurent, C.; Buée, L.; Blum, D. Tau and Neuroinflammation: What Impact for Alzheimer's Disease and Tauopathies? Biomed. J. 2018, 41, 21-33. [CrossRef]

14. Kametani, F.; Hasegawa, M. Reconsideration of Amyloid Hypothesis and Tau Hypothesis in Alzheimer's Disease. Front. Neurosci. 2018, 12, 25. [CrossRef]

15. Shi, Y.; Yamada, K.; Liddelow, S.A.; Smith, S.T.; Zhao, L.; Luo, W.; Tsai, R.M.; Spina, S.; Grinberg, L.T.; Rojas, J.C. ApoE4 Markedly Exacerbates Tau-Mediated Neurodegeneration in a Mouse Model of Tauopathy. Nature 2017, 549, 523-527. [CrossRef]

16. Chen, Y.; Strickland, M.R.; Soranno, A.; Holtzman, D.M. Apolipoprotein E: Structural Insights and Links to Alzheimer Disease Pathogenesis. Neuron 2020, 109, 205-221. [CrossRef] [PubMed]

17. Shi, Y.; Andhey, P.S.; Ising, C.; Wang, K.; Snipes, L.L.; Boyer, K.; Lawson, S.; Yamada, K.; Qin, W.; Manis, M. Overexpressing Low-Density Lipoprotein Receptor Reduces Tau-Associated Neurodegeneration in Relation to ApoE-Linked Mechanisms. Neuron 2021, 109, 2413-2426.e7. [CrossRef] [PubMed]

18. Panegyres, P.K.; Chen, H.-Y. Differences between Early and Late Onset Alzheimer's Disease. Am. J. Neurodegener. Dis. 2013, 2, 300. [PubMed]

19. Efthymiou, A.G.; Goate, A.M. Late Onset Alzheimer's Disease Genetics Implicates Microglial Pathways in Disease Risk. Mol. Neurodegener. 2017, 12, 1-12. [CrossRef] [PubMed]

20. Tanzi, R.E. The Genetics of Alzheimer Disease. Cold Spring Harb. Perspect. Med. 2012, 2, a006296. [CrossRef] [PubMed]

21. Akiyama, H.; Barger, S.; Barnum, S.; Bradt, B.; Bauer, J.; Cole, G.M.; Cooper, N.R.; Eikelenboom, P.; Emmerling, M.; Fiebich, B.L. Inflammation and Alzheimer's Disease. Neurobiol. Aging 2000, 21, 383-421. [CrossRef]

22. Wyss-Coray, T.; Rogers, J. Inflammation in Alzheimer Disease-a Brief Review of the Basic Science and Clinical Literature. Cold Spring Harb. Perspect. Med. 2012, 2, a006346. [CrossRef] [PubMed]

23. Hampel, H.; Caraci, F.; Cuello, A.C.; Caruso, G.; Nisticò, R.; Corbo, M.; Baldacci, F.; Toschi, N.; Garaci, F.; Chiesa, P.A. A Path toward Precision Medicine for Neuroinflammatory Mechanisms in Alzheimer's Disease. Front. Immunol. 2020, 11, 456. [CrossRef] [PubMed]

24. Hardy, J.; Selkoe, D.J. The Amyloid Hypothesis of Alzheimer's Disease: Progress and Problems on the Road to Therapeutics. Science 2002, 297, 353-356. [CrossRef] [PubMed]

25. O'brien, R.J.; Wong, P.C. Amyloid Precursor Protein Processing and Alzheimer's Disease. Annu. Rev. Neurosci. 2011, 34, 185-204. [CrossRef] [PubMed]

26. Zhang, H.; Ma, Q.; Zhang, Y.; Xu, H. Proteolytic Processing of Alzheimer's B-amyloid Precursor Protein. J. Neurochem. REVIEW 2012, 120, 9-21. [CrossRef] [PubMed]

27. Yoon, S.-S.; Jo, S.A. Mechanisms of Amyloid- $\beta$ Peptide Clearance: Potential Therapeutic Targets for Alzheimer's Disease. Biomol. Ther. 2012, 20, 245. [CrossRef]

28. Kwon, S.; Moreno-Gonzalez, I.; Taylor-Presse, K.; Edwards, G., III; Gamez, N.; Calderon, O.; Zhu, B.; Velasquez, F.C.; Soto, C.; Sevick-Muraca, E.M. Impaired Peripheral Lymphatic Function and Cerebrospinal Fluid Outflow in a Mouse Model of Alzheimer's Disease. J. Alzheimer's Dis. 2019, 69, 585-593. [CrossRef]

29. Sun, X.; Chen, W.-D.; Wang, Y.-D. $\beta$-Amyloid: The Key Peptide in the Pathogenesis of Alzheimer's Disease. Front. Pharmacol. 2015, 6, 221. [CrossRef]

30. Deane, R.; Bell, R.D.; Sagare, A.; Zlokovic, B.V. Clearance of Amyloid- $\beta$ Peptide across the Blood-Brain Barrier: Implication for Therapies in Alzheimer's Disease. CNS Neurol. Disord. -Drug Targets Former. Curr. Drug Targets-CNS Neurol. Disord. 2009, 8, 16-30. [CrossRef] 
31. Walsh, D.M.; Klyubin, I.; Fadeeva, J.V.; Cullen, W.K.; Anwyl, R.; Wolfe, M.S.; Rowan, M.J.; Selkoe, D.J. Naturally Secreted Oligomers of Amyloid $\beta$ Protein Potently Inhibit Hippocampal Long-Term Potentiation in Vivo. Nature 2002, 416, 535-539. [CrossRef]

32. Castellani, R.J.; Smith, M.A. Compounding Artefacts with Uncertainty, and an Amyloid Cascade Hypothesis That Is 'Too Big to Fail'. J. Pathol. 2011, 224, 147-152. [CrossRef]

33. Alexander, G.C.; Emerson, S.; Kesselheim, A.S. Evaluation of Aducanumab for Alzheimer Disease: Scientific Evidence and Regulatory Review Involving Efficacy, Safety, and Futility. JAMA 2021, 325, 1717-1718. [CrossRef]

34. Karran, E.; Mercken, M.; de Strooper, B. The Amyloid Cascade Hypothesis for Alzheimer's Disease: An Appraisal for the Development of Therapeutics. Nat. Rev. Drug Discov. 2011, 10, 698-712. [CrossRef] [PubMed]

35. Knopman, D.S.; Jones, D.T.; Greicius, M.D. Failure to Demonstrate Efficacy of Aducanumab: An Analysis of the EMERGE and ENGAGE Trials as Reported by Biogen, December 2019. Alzheimer's Dement. 2021, 17, 696-701. [CrossRef]

36. Jimenez, S.; Baglietto-Vargas, D.; Caballero, C.; Moreno-Gonzalez, I.; Torres, M.; Sanchez-Varo, R.; Ruano, D.; Vizuete, M.; Gutierrez, A.; Vitorica, J. Inflammatory Response in the Hippocampus of PS1M146L/APP751SL Mouse Model of Alzheimer's Disease: Age-Dependent Switch in the Microglial Phenotype from Alternative to Classic. J. Neurosci. 2008, 28, 11650-11661. [CrossRef]

37. McGeer, P.L.; McGeer, E.G. The Amyloid Cascade-Inflammatory Hypothesis of Alzheimer Disease: Implications for Therapy. Acta Neuropathol. 2013, 126, 479-497. [CrossRef]

38. Kidd, M. Paired Helical Filaments in Electron Microscopy of Alzheimer's Disease. Nature 1963, 197, 192-193. [CrossRef] [PubMed]

39. Lee, V.M.Y.; Goedert, M.; Trojanowski, J.Q. Neurodegenerative Tauopathies. Annu. Rev. Neurosci. 2001, 24, 1121-1159. [CrossRef]

40. Sinsky, J.; Pichlerova, K.; Hanes, J. Tau Protein Interaction Partners and Their Roles in Alzheimer's Disease and Other Tauopathies. Int. J. Mol. Sci. 2021, 22, 9207. [CrossRef] [PubMed]

41. Serrano-Pozo, A.; Frosch, M.P.; Masliah, E.; Hyman, B.T. Neuropathological Alterations in Alzheimer Disease. Cold Spring Harb. Perspect. Med. 2011, 1, a006189. [CrossRef]

42. Weingarten, M.D.; Lockwood, A.H.; Hwo, S.-Y.; Kirschner, M.W. A Protein Factor Essential for Microtubule Assembly. Proc. Natl. Acad. Sci. USA 1975, 72, 1858-1862. [CrossRef]

43. LoPresti, P.; Szuchet, S.; Papasozomenos, S.C.; Zinkowski, R.P.; Binder, L.I. Functional Implications for the Microtubule-Associated Protein Tau: Localization in Oligodendrocytes. Proc. Natl. Acad. Sci. USA 1995, 92, 10369-10373. [CrossRef]

44. Zhang, Y.; Chen, K.; Sloan, S.A.; Bennett, M.L.; Scholze, A.R.; O’Keeffe, S.; Phatnani, H.P.; Guarnieri, P.; Caneda, C.; Ruderisch, N. An RNA-Sequencing Transcriptome and Splicing Database of Glia, Neurons, and Vascular Cells of the Cerebral Cortex. J. Neurosci. 2014, 34, 11929-11947. [CrossRef] [PubMed]

45. Zheng, H.; Liu, C.-C.; Atagi, Y.; Chen, X.-F.; Jia, L.; Yang, L.; He, W.; Zhang, X.; Kang, S.S.; Rosenberry, T.L. Opposing Roles of the Triggering Receptor Expressed on Myeloid Cells 2 and Triggering Receptor Expressed on Myeloid Cells-like Transcript 2 in Microglia Activation. Neurobiol. Aging 2016, 42, 132-141. [CrossRef] [PubMed]

46. Zhang, H.; Cao, Y.; Ma, L.; Wei, Y.; Li, H. Possible Mechanisms of Tau Spread and Toxicity in Alzheimer's Disease. Front. Cell Dev. Biol. 2021, 2064.

47. Cras, P.; Kawai, M.; Lowery, D.; Gonzalez-DeWhitt, P.; Greenberg, B.; Perry, G. Senile Plaque Neurites in Alzheimer Disease Accumulate Amyloid Precursor Protein. Proc. Natl. Acad. Sci. USA 1991, 88, 7552-7556. [CrossRef]

48. Games, D.; Adams, D.; Alessandrini, R.; Barbour, R.; Borthelette, P.; Blackwell, C.; Carr, T.; Clemens, J.; Donaldson, T.; Gillespie, F. Alzheimer-Type Neuropathology in Transgenic Mice Overexpressing V717F $\beta$-Amyloid Precursor Protein. Nature 1995, 373, 523-527. [CrossRef]

49. McNamara, M.J.; Ruff, C.T.; Wasco, W.; Tanzi, R.E.; Thinakaran, G.; Hyman, B.T. Immunohistochemical and in Situ Analysis of Amyloid Precursor-like Protein-1 and Amyloid Precursor-like Protein-2 Expression in Alzheimer Disease and Aged Control Brains. Brain Res. 1998, 804, 45-51. [CrossRef]

50. Hurtado, D.E.; Molina-Porcel, L.; Iba, M.; Aboagye, A.K.; Paul, S.M.; Trojanowski, J.Q.; Lee, V.M.-Y. A $\beta$ Accelerates the Spatiotemporal Progression of Tau Pathology and Augments Tau Amyloidosis in an Alzheimer Mouse Model. Am. J. Pathol. 2010, 177, 1977-1988. [CrossRef]

51. Schönheit, B.; Zarski, R.; Ohm, T.G. Spatial and Temporal Relationships between Plaques and Tangles in Alzheimer-Pathology. Neurobiol. Aging 2004, 25, 697-711. [CrossRef]

52. van der Kant, R.; Goldstein, L.S.B.; Ossenkoppele, R. Amyloid- $\beta$-Independent Regulators of Tau Pathology in Alzheimer Disease. Nat. Rev. Neurosci. 2020, 21, 21-35. [CrossRef]

53. Braak, H.; Braak, E.V.A. Staging of Alzheimer's Disease-Related Neurofibrillary Changes. Neurobiol. Aging 1995, 16, 271-278. [CrossRef]

54. Thal, D.R.; Rüb, U.; Orantes, M.; Braak, H. Phases of A $\beta$-Deposition in the Human Brain and Its Relevance for the Development of AD. Neurology 2002, 58, 1791-1800. [CrossRef] [PubMed]

55. Hyman, B.T.; Phelps, C.H.; Beach, T.G.; Bigio, E.H.; Cairns, N.J.; Carrillo, M.C.; Dickson, D.W.; Duyckaerts, C.; Frosch, M.P.; Masliah, E. National Institute on Aging-Alzheimer's Association Guidelines for the Neuropathologic Assessment of Alzheimer's Disease. Alzheimer's Dement. 2012, 8, 1-13. [CrossRef]

56. Boche, D.; Nicoll, J.A.R. Invited Review-Understanding Cause and Effect in Alzheimer's Pathophysiology: Implications for Clinical Trials. Neuropathol. Appl. Neurobiol. 2020, 46, 623-640. [CrossRef] 
57. Gratuze, M.; Chen, Y.; Parhizkar, S.; Jain, N.; Strickland, M.R.; Serrano, J.R.; Colonna, M.; Ulrich, J.D.; Holtzman, D.M. Activated Microglia Mitigate A $\beta$-Associated Tau Seeding and Spreading. J. Exp. Med. 2021, 218, e20210542. [CrossRef]

58. Chaplin, D.D. Overview of the Immune Response. J. Allergy Clin. Immunol. 2010, 125, S3-S23. [CrossRef] [PubMed]

59. Bachiller, S.; Jiménez-Ferrer, I.; Paulus, A.; Yang, Y.; Swanberg, M.; Deierborg, T.; Boza-Serrano, A. Microglia in Neurological Diseases: A Road Map to Brain-Disease Dependent-Inflammatory Response. Front. Cell. Neurosci. 2018, 12, 488. [CrossRef] [PubMed]

60. Keren-Shaul, H.; Spinrad, A.; Weiner, A.; Matcovitch-Natan, O.; Dvir-Szternfeld, R.; Ulland, T.K.; David, E.; Baruch, K.; LaraAstaiso, D.; Toth, B. A Unique Microglia Type Associated with Restricting Development of Alzheimer's Disease. Cell 2017, 169, 1276-1290. [CrossRef] [PubMed]

61. Deczkowska, A.; Keren-Shaul, H.; Weiner, A.; Colonna, M.; Schwartz, M.; Amit, I. Disease-Associated Microglia: A Universal Immune Sensor of Neurodegeneration. Cell 2018, 173, 1073-1081. [CrossRef]

62. Swardfager, W.; Lanctôt, K.; Rothenburg, L.; Wong, A.; Cappell, J.; Herrmann, N. A Meta-Analysis of Cytokines in Alzheimer's Disease. Biol. Psychiatry 2010, 68, 930-941. [CrossRef]

63. Jack, C.R., Jr.; Knopman, D.S.; Jagust, W.J.; Petersen, R.C.; Weiner, M.W.; Aisen, P.S.; Shaw, L.M.; Vemuri, P.; Wiste, H.J.; Weigand, S.D. Tracking Pathophysiological Processes in Alzheimer's Disease: An Updated Hypothetical Model of Dynamic Biomarkers. Lancet Neurol. 2013, 12, 207-216. [CrossRef]

64. Zhang, R.; Miller, R.G.; Madison, C.; Jin, X.; Honrada, R.; Harris, W.; Katz, J.; Forshew, D.A.; McGrath, M.S. Systemic Immune System Alterations in Early Stages of Alzheimer's Disease. J. Neuroimmunol. 2013, 256, 38-42. [CrossRef]

65. Dursun, E.; Gezen-Ak, D.; Hanağası, H.; Bilgiç, B.; Lohmann, E.; Ertan, S.; Atasoy, İ.L.; Alaylığlu, M.; Araz, Ö.S.; Önal, B. The Interleukin 1 Alpha, Interleukin 1 Beta, Interleukin 6 and Alpha-2-Macroglobulin Serum Levels in Patients with Early or Late Onset Alzheimer's Disease, Mild Cognitive Impairment or Parkinson's Disease. J. Neuroimmunol. 2015, 283, 50-57. [CrossRef] [PubMed]

66. Park, J.-C.; Han, S.-H.; Mook-Jung, I. Peripheral Inflammatory Biomarkers in Alzheimer's Disease: A Brief Review. BMB Rep. 2020, 53, 10. [CrossRef] [PubMed]

67. Solfrizzi, V.; D’Introno, A.; Colacicco, A.M.; Capurso, C.; Todarello, O.; Pellicani, V.; Capurso, S.A.; Pietrarossa, G.; Santamato, V.; Capurso, A. Circulating Biomarkers of Cognitive Decline and Dementia. Clin. Chim. Acta 2006, 364, 91-112. [CrossRef] [PubMed]

68. Harries, L.W.; Bradley-Smith, R.M.; Llewellyn, D.J.; Pilling, L.C.; Fellows, A.; Henley, W.; Hernandez, D.; Guralnik, J.M.; Bandinelli, S.; Singleton, A. Leukocyte CCR2 Expression Is Associated with Mini-Mental State Examination Score in Older Adults. Rejuvenation Res. 2012, 15, 395-404. [CrossRef] [PubMed]

69. Westin, K.; Buchhave, P.; Nielsen, H.; Minthon, L.; Janciauskiene, S.; Hansson, O. CCL2 Is Associated with a Faster Rate of Cognitive Decline during Early Stages of Alzheimer's Disease. PLoS ONE 2012, 7, e30525. [CrossRef] [PubMed]

70. Lambert, J.-C.; Ibrahim-Verbaas, C.A.; Harold, D.; Naj, A.C.; Sims, R.; Bellenguez, C.; Jun, G.; DeStefano, A.L.; Bis, J.C.; Beecham, G.W. Meta-Analysis of 74,046 Individuals Identifies 11 New Susceptibility Loci for Alzheimer's Disease. Nat. Genet. 2013, 45, 1452-1458. [CrossRef] [PubMed]

71. Ridge, P.G.; Hoyt, K.B.; Boehme, K.; Mukherjee, S.; Crane, P.K.; Haines, J.L.; Mayeux, R.; Farrer, L.A.; Pericak-Vance, M.A.; Schellenberg, G.D. Assessment of the Genetic Variance of Late-Onset Alzheimer's Disease. Neurobiol. Aging 2016, 41, 200.e13200.e20. [CrossRef]

72. Sims, R.; van der Lee, S.J.; Naj, A.C.; Bellenguez, C.; Badarinarayan, N.; Jakobsdottir, J.; Kunkle, B.W.; Boland, A.; Raybould, R.; Bis, J.C. Rare Coding Variants in PLCG2, ABI3, and TREM2 Implicate Microglial-Mediated Innate Immunity in Alzheimer's Disease. Nat. Genet. 2017, 49, 1373-1384. [CrossRef]

73. Garcez, M.L.; Mina, F.; Bellettini-Santos, T.; Carneiro, F.G.; Luz, A.P.; Schiavo, G.L.; Andrighetti, M.S.; Scheid, M.G.; Bolfe, R.P.; Budni, J. Minocycline Reduces Inflammatory Parameters in the Brain Structures and Serum and Reverses Memory Impairment Caused by the Administration of Amyloid $\beta$ (1-42) in Mice. Prog. Neuro-Psychopharmacol. Biol. Psychiatry 2017, 77, 23-31. [CrossRef]

74. Yang, T.; Li, S.; Xu, H.; Walsh, D.M.; Selkoe, D.J. Large Soluble Oligomers of Amyloid $\beta$-Protein from Alzheimer Brain Are Far Less Neuroactive than the Smaller Oligomers to Which They Dissociate. J. Neurosci. 2017, 37, 152-163. [CrossRef]

75. Garcez, M.L.; Mina, F.; Bellettini-Santos, T.; da Luz, A.P.; Schiavo, G.L.; Macieski, J.M.C.; Medeiros, E.B.; Marques, A.O.; Magnus, N.Q.; Budni, J. The Involvement of NLRP3 on the Effects of Minocycline in an AD-like Pathology Induced by $\beta$-Amyloid Oligomers Administered to Mice. Mol. Neurobiol. 2019, 56, 2606-2617. [CrossRef]

76. Barry, A.E.; Klyubin, I.; Mc Donald, J.M.; Mably, A.J.; Farrell, M.A.; Scott, M.; Walsh, D.M.; Rowan, M.J. Alzheimer's Disease Brain-Derived Amyloid- $\beta$-Mediated Inhibition of LTP in Vivo Is Prevented by Immunotargeting Cellular Prion Protein. J. Neurosci. 2011, 31, 7259-7263. [CrossRef]

77. Borlikova, G.G.; Trejo, M.; Mably, A.J.; Mc Donald, J.M.; Frigerio, C.S.; Regan, C.M.; Murphy, K.J.; Masliah, E.; Walsh, D.M. Alzheimer Brain-Derived Amyloid $\beta$-Protein Impairs Synaptic Remodeling and Memory Consolidation. Neurobiol. Aging 2013, 34, 1315-1327. [CrossRef] [PubMed]

78. Quintanilla, R.A.; Orellana, D.I.; González-Billault, C.; Maccioni, R.B. Interleukin-6 Induces Alzheimer-Type Phosphorylation of Tau Protein by Deregulating the Cdk5/P35 Pathway. Exp. Cell Res. 2004, 295, 245-257. [CrossRef] [PubMed]

79. Kigerl, K.A.; de Rivero Vaccari, J.P.; Dietrich, W.D.; Popovich, P.G.; Keane, R.W. Pattern Recognition Receptors and Central Nervous System Repair. Exp. Neurol. 2014, 258, 5-16. [CrossRef] [PubMed] 
80. Lin, L.; Huang, Q.-X.; Yang, S.-S.; Chu, J.; Wang, J.-Z.; Tian, Q. Melatonin in Alzheimer's Disease. Int. J. Mol. Sci. 2013, 14, 14575-14593. [CrossRef] [PubMed]

81. Serrano-Pozo, A.; Muzikansky, A.; Gómez-Isla, T.; Growdon, J.H.; Betensky, R.A.; Frosch, M.P.; Hyman, B.T. Differential Relationships of Reactive Astrocytes and Microglia to Fibrillar Amyloid Deposits in Alzheimer Disease. J. Neuropathol. Exp. Neurol. 2013, 72, 462-471. [CrossRef]

82. Serrano-Pozo, A.; Betensky, R.A.; Frosch, M.P.; Hyman, B.T. Plaque-Associated Local Toxicity Increases over the Clinical Course of Alzheimer Disease. Am. J. Pathol. 2016, 186, 375-384. [CrossRef]

83. Zolezzi, J.M.; Inestrosa, N.C. Wnt/TLR Dialog in Neuroinflammation, Relevance in Alzheimer's Disease. Front. Immunol. 2017, 8, 187. [CrossRef]

84. el Khoury, J.B.; Moore, K.J.; Means, T.K.; Leung, J.; Terada, K.; Toft, M.; Freeman, M.W.; Luster, A.D. CD36 Mediates the Innate Host Response to $\beta$-Amyloid. J. Exp. Med. 2003, 197, 1657-1666. [CrossRef]

85. Lukose, B.; Rani, P. G82S RAGE Polymorphism Influences Amyloid-RAGE Interactions Relevant in Alzheimer's Disease Pathology. PLOS ONE 2020, 15, e0225487.

86. Udan, M.L.D.; Ajit, D.; Crouse, N.R.; Nichols, M.R. Toll-like Receptors 2 and 4 Mediate A $\beta$ (1-42) Activation of the Innate Immune Response in a Human Monocytic Cell Line. J. Neurochem. 2008, 104, 524-533. [CrossRef]

87. Liu, S.; Liu, Y.; Hao, W.; Wolf, L.; Kiliaan, A.J.; Penke, B.; Rübe, C.E.; Walter, J.; Heneka, M.T.; Hartmann, T. TLR2 Is a Primary Receptor for Alzheimer's Amyloid $\beta$ Peptide to Trigger Neuroinflammatory Activation. J. Immunol. 2012, 188, $1098-1107$. [CrossRef] [PubMed]

88. Balducci, C.; Frasca, A.; Zotti, M.; la Vitola, P.; Mhillaj, E.; Grigoli, E.; Iacobellis, M.; Grandi, F.; Messa, M.; Colombo, L. Tolllike Receptor 4-Dependent Glial Cell Activation Mediates the Impairment in Memory Establishment Induced by $\beta$-Amyloid Oligomers in an Acute Mouse Model of Alzheimer's Disease. Brain Behav. Immun. 2017, 60, 188-197. [CrossRef] [PubMed]

89. Babić Leko, M.; Nikolac Perković, M.; Klepac, N.; Štrac, D.Š.; Borovečki, F.; Pivac, N.; Hof, P.R.; Šimić, G. IL-1ß, IL-6, IL-10, and TNF $\alpha$ Single Nucleotide Polymorphisms in Human Influence the Susceptibility to Alzheimer's Disease Pathology. J. Alzheimer's Dis. 2020, 75, 1029-1047. [CrossRef] [PubMed]

90. Heneka, M.T.; Kummer, M.P.; Latz, E. Innate Immune Activation in Neurodegenerative Disease. Nat. Rev. Immunol. 2014, 14, 463-477. [CrossRef]

91. Parajuli, B.; Sonobe, Y.; Horiuchi, H.; Takeuchi, H.; Mizuno, T.; Suzumura, A. Oligomeric Amyloid $\beta$ Induces IL-1 $\beta$ Processing via Production of ROS: Implication in Alzheimer's Disease. Cell Death Dis. 2013, 4, e975. [CrossRef]

92. Halle, A.; Hornung, V.; Petzold, G.C.; Stewart, C.R.; Monks, B.G.; Reinheckel, T.; Fitzgerald, K.A.; Latz, E.; Moore, K.J.; Golenbock, D.T. The NALP3 Inflammasome Is Involved in the Innate Immune Response to Amyloid- $\beta$. Nat. Immunol. 2008, 9, 857-865. [CrossRef]

93. Yang, F.; Wang, Z.; Wei, X.; Han, H.; Meng, X.; Zhang, Y.; Shi, W.; Li, F.; Xin, T.; Pang, Q. NLRP3 Deficiency Ameliorates Neurovascular Damage in Experimental Ischemic Stroke. J. Cereb. Blood Flow Metab. 2014, 34, 660-667. [CrossRef]

94. Tan, M.-S.; Yu, J.-T.; Jiang, T.; Zhu, X.-C.; Tan, L. The NLRP3 Inflammasome in Alzheimer's Disease. Mol. Neurobiol. 2013, 48, 875-882. [CrossRef] [PubMed]

95. Daniels, M.J.D.; Rivers-Auty, J.; Schilling, T.; Spencer, N.G.; Watremez, W.; Fasolino, V.; Booth, S.J.; White, C.S.; Baldwin, A.G.; Freeman, S. Fenamate NSAIDs Inhibit the NLRP3 Inflammasome and Protect against Alzheimer's Disease in Rodent Models. Nat. Commun. 2016, 7, 1-10. [CrossRef] [PubMed]

96. Song, L.; Pei, L.; Yao, S.; Wu, Y.; Shang, Y. NLRP3 Inflammasome in Neurological Diseases, from Functions to Therapies. Front. Cell. Neurosci. 2017, 11, 63. [CrossRef] [PubMed]

97. Sagulenko, V.; Thygesen, S.J.; Sester, D.P.; Idris, A.; Cridland, J.A.; Vajjhala, P.R.; Roberts, T.L.; Schroder, K.; Vince, J.E.; Hill, J.M. AIM2 and NLRP3 Inflammasomes Activate Both Apoptotic and Pyroptotic Death Pathways via ASC. Cell Death Differ. 2013, 20, 1149-1160. [CrossRef]

98. Venegas, C.; Kumar, S.; Franklin, B.S.; Dierkes, T.; Brinkschulte, R.; Tejera, D.; Vieira-Saecker, A.; Schwartz, S.; Santarelli, F.; Kummer, M.P. Microglia-Derived ASC Specks Cross-Seed Amyloid- $\beta$ in Alzheimer's Disease. Nature 2017, 552, $355-361$. [CrossRef]

99. Liu, C.; Cui, G.; Zhu, M.; Kang, X.; Guo, H. Neuroinflammation in Alzheimer's Disease: Chemokines Produced by Astrocytes and Chemokine Receptors. Int. J. Clin. Exp. Pathol. 2014, 7, 8342.

100. Gold, M.; el Khoury, J. $\beta$-Amyloid, Microglia, and the Inflammasome in Alzheimer's Disease. In Seminars in Immunopathology; Springer: Berlin/Heidelberg, Germany, 2015; Volume 37, pp. 607-611.

101. Merino, J.J.; Muñetón-Gómez, V.; Alvárez, M.-I.; Toledano-Díaz, A. Effects of Cx3cr1 and Fractalkine Chemokines in Amyloid Beta Clearance and P-Tau Accumulation in Alzheimer, s Disease (Ad) Rodent Models: Is Fractalkine a Systemic Biomarker for Ad? Curr. Alzheimer Res. 2016, 13, 403-412. [CrossRef]

102. Mecca, C.; Giambanco, I.; Donato, R.; Arcuri, C. Microglia and Aging: The Role of the TREM2-DAP12 and CX3CL1-CX3CR1 Axes. Int. J. Mol. Sci. 2018, 19, 318. [CrossRef]

103. Wang, H.; Shen, Y.; Chuang, H.; Chiu, C.; Ye, Y.; Zhao, L. Neuroinflammation in Alzheimer's Disease: Microglia, Molecular Participants and Therapeutic Choices. Curr. Alzheimer Res. 2019, 16, 659-674. [CrossRef]

104. Butler, A.W.; Ng, M.Y.M.; Hamshere, M.L.; Forabosco, P.; Wroe, R.; Al-Chalabi, A.; Lewis, C.M.; Powell, J.F. Meta-Analysis of Linkage Studies for Alzheimer's Disease—a Web Resource. Neurobiol. Aging 2009, 30, 1037-1047. [CrossRef] [PubMed] 
105. Guerreiro, R.; Wojtas, A.; Bras, J.; Carrasquillo, M.; Rogaeva, E.; Majounie, E.; Cruchaga, C.; Sassi, C.; Kauwe, J.S.K.; Younkin, S. TREM2 Variants in Alzheimer's Disease. N. Engl. J. Med. 2013, 368, 117-127. [CrossRef] [PubMed]

106. Roussos, P.; Katsel, P.; Fam, P.; Tan, W.; Purohit, D.P.; Haroutunian, V. The Triggering Receptor Expressed on Myeloid Cells 2 (TREM2) Is Associated with Enhanced Inflammation, Neuropathological Lesions and Increased Risk for Alzheimer's Dementia. Alzheimer's Dement. 2015, 11, 1163-1170. [CrossRef] [PubMed]

107. Kober, D.L.; Stuchell-Brereton, M.D.; Kluender, C.E.; Dean, H.B.; Strickland, M.R.; Steinberg, D.F.; Nelson, S.S.; Baban, B.; Holtzman, D.M.; Frieden, C. Functional Insights from Biophysical Study of TREM2 Interactions with ApoE and A $\beta 1-42$. Alzheimer's Dement. 2021, 17, 475-488. [CrossRef]

108. Gratuze, M.; Leyns, C.E.G.; Holtzman, D.M. New Insights into the Role of TREM2 in Alzheimer's Disease. Mol. Neurodegener. 2018, 13, 1-16. [CrossRef] [PubMed]

109. Kober, D.L.; Brett, T.J. TREM2-Ligand Interactions in Health and Disease. J. Mol. Biol. 2017, 429, 1607-1629. [CrossRef]

110. Kleinberger, G.; Brendel, M.; Mracsko, E.; Wefers, B.; Groeneweg, L.; Xiang, X.; Focke, C.; Deußing, M.; Suárez-Calvet, M.; Mazaheri, F. The FTD-like Syndrome Causing TREM 2 T66M Mutation Impairs Microglia Function, Brain Perfusion, and Glucose Metabolism. EMBO J. 2017, 36, 1837-1853. [CrossRef]

111. Wunderlich, P.; Glebov, K.; Kemmerling, N.; Tien, N.T.; Neumann, H.; Walter, J. Sequential Proteolytic Processing of the Triggering Receptor Expressed on Myeloid Cells-2 (TREM2) Protein by Ectodomain Shedding and $\gamma$-Secretase-Dependent Intramembranous Cleavage. J. Biol. Chem. 2013, 288, 33027-33036. [CrossRef]

112. Deczkowska, A.; Weiner, A.; Amit, I. The Physiology, Pathology, and Potential Therapeutic Applications of the TREM2 Signaling Pathway. Cell 2020, 181, 1207-1217. [CrossRef]

113. Zhong, L.; Wang, Z.; Wang, D.; Wang, Z.; Martens, Y.A.; Wu, L.; Xu, Y.; Wang, K.; Li, J.; Huang, R. Amyloid-Beta Modulates Microglial Responses by Binding to the Triggering Receptor Expressed on Myeloid Cells 2 (TREM2). Mol. Neurodegener. 2018, 13, 1-12. [CrossRef]

114. Caldeira, C.; Oliveira, A.F.; Cunha, C.; Vaz, A.R.; Falcão, A.S.; Fernandes, A.; Brites, D. Microglia Change from a Reactive to an Age-like Phenotype with the Time in Culture. Front. Cell. Neurosci. 2014, 8, 152. [CrossRef]

115. Davies, D.S.; Ma, J.; Jegathees, T.; Goldsbury, C. Microglia Show Altered Morphology and Reduced Arborization in Human Brain during Aging and A Lzheimer's Disease. Brain Pathol. 2017, 27, 795-808. [CrossRef]

116. Lee, C.Y.D.; Daggett, A.; Gu, X.; Jiang, L.-L.; Langfelder, P.; Li, X.; Wang, N.; Zhao, Y.; Park, C.S.; Cooper, Y. Elevated TREM2 Gene Dosage Reprograms Microglia Responsivity and Ameliorates Pathological Phenotypes in Alzheimer's Disease Models. Neuron 2018, 97, 1032-1048. [CrossRef]

117. Yuan, P.; Condello, C.; Keene, C.D.; Wang, Y.; Bird, T.D.; Paul, S.M.; Luo, W.; Colonna, M.; Baddeley, D.; Grutzendler, J. TREM2 Haplodeficiency in Mice and Humans Impairs the Microglia Barrier Function Leading to Decreased Amyloid Compaction and Severe Axonal Dystrophy. Neuron 2016, 90, 724-739. [CrossRef]

118. van Acker, Z.P.; Perdok, A.; Bretou, M.; Annaert, W. The Microglial Lysosomal System in Alzheimer's Disease: Guardian against Proteinopathy. Ageing Res. Rev. 2021, 101444. [CrossRef]

119. Regen, F.; Hellmann-Regen, J.; Costantini, E.; Reale, M. Neuroinflammation and Alzheimer's Disease: Implications for Microglial Activation. Curr. Alzheimer Res. 2017, 14, 1140-1148. [CrossRef] [PubMed]

120. Casali, B.T.; Reed-Geaghan, E.G. Microglial Function and Regulation during Development, Homeostasis and Alzheimer's Disease. Cells 2021, 10, 957. [CrossRef]

121. Daneman, R.; Prat, A. The Blood-Brain Barrier. Cold Spring Harb. Perspect. Biol. 2015, 7, a020412. [CrossRef] [PubMed]

122. Weiss, N.; Miller, F.; Cazaubon, S.; Couraud, P.-O. The Blood-Brain Barrier in Brain Homeostasis and Neurological Diseases. Biochim. Biophys. Acta (BBA)-Biomembr. 2009, 1788, 842-857. [CrossRef] [PubMed]

123. Yamazaki, Y.; Kanekiyo, T. Blood-Brain Barrier Dysfunction and the Pathogenesis of Alzheimer's Disease. Int. J. Mol. Sci. 2017, 18, 1965. [CrossRef]

124. Bowman, G.L.; Kaye, J.A.; Moore, M.; Waichunas, D.; Carlson, N.E.; Quinn, J.F. Blood-Brain Barrier Impairment in Alzheimer Disease: Stability and Functional Significance. Neurology 2007, 68, 1809-1814. [CrossRef]

125. Zlokovic, B.V. The Blood-Brain Barrier in Health and Chronic Neurodegenerative Disorders. Neuron 2008, 57, 178-201. [CrossRef]

126. Dickstein, D.L.; Walsh, J.; Brautigam, H.; Stockton, S.D., Jr.; Gandy, S.; Hof, P.R. Role of Vascular Risk Factors and Vascular Dysfunction in Alzheimer's Disease. Mt. Sinai J. Med. J. Transl. Pers. Med. 2010, 77, 82-102. [CrossRef]

127. Zhao, Z.; Nelson, A.R.; Betsholtz, C.; Zlokovic, B.V. Establishment and Dysfunction of the Blood-Brain Barrier. Cell 2015, 163, 1064-1078. [CrossRef] [PubMed]

128. Ujiie, M.; Dickstein, D.L.; Carlow, D.A.; Jefferies, W.A. Blood-Brain Barrier Permeability Precedes Senile Plaque Formation in an Alzheimer Disease Model. Microcirculation 2003, 10, 463-470.

129. van de Haar, H.J.; Burgmans, S.; Jansen, J.F.A.; van Osch, M.J.P.; van Buchem, M.A.; Muller, M.; Hofman, P.A.M.; Verhey, F.R.J.; Backes, W.H. Blood-Brain Barrier Leakage in Patients with Early Alzheimer Disease. Radiology 2016, 281, 527-535. [CrossRef] [PubMed]

130. Wisniewski, H.M.; Kozlowski, P.B. Evidence for Blood-brain Barrier Changes in Senile Dementia of the Alzheimer Type (SDAT). Ann. N. Y. Acad. Sci. 1982, 396, 119-129. [CrossRef] [PubMed]

131. Wisniewski, H.M.; Vorbrodt, A.W.; Wegiel, J. Amyloid Angiopathy and Blood-Brain Barrier Changes in Alzheimer's Disease a, b. Ann. N. Y. Acad. Sci. 1997, 826, 161-172. [CrossRef] [PubMed] 
132. Erickson, M.A.; Banks, W.A. Blood-Brain Barrier Dysfunction as a Cause and Consequence of Alzheimer's Disease. J. Cereb. Blood Flow Metab. 2013, 33, 1500-1513. [CrossRef] [PubMed]

133. de Reuck, J.L. The Significance of Small Cerebral Bleeds in Neurodegenerative Dementia Syndromes. Aging Dis. $2012,3,307$.

134. Wang, D.; Chen, F.; Han, Z.; Yin, Z.; Ge, X.; Lei, P. Relationship Between Amyloid- $\beta$ Deposition and Blood-Brain Barrier Dysfunction in Alzheimer's Disease. Front. Cell. Neurosci. 2021, 15, 271. [CrossRef]

135. Shibata, M.; Yamada, S.; Kumar, S.R.; Calero, M.; Bading, J.; Frangione, B.; Holtzman, D.M.; Miller, C.A.; Strickland, D.K.; Ghiso, J. Clearance of Alzheimer's Amyloid- $\beta$ 1-40 Peptide from Brain by LDL Receptor-Related Protein-1 at the Blood-Brain Barrier. J. Clin. Investig. 2000, 106, 1489-1499. [CrossRef]

136. Donahue, J.E.; Flaherty, S.L.; Johanson, C.E.; Duncan, J.A.; Silverberg, G.D.; Miller, M.C.; Tavares, R.; Yang, W.; Wu, Q.; Sabo, E. RAGE, LRP-1, and Amyloid-Beta Protein in Alzheimer's Disease. Acta Neuropathol. 2006, 112, 405-415. [CrossRef]

137. Gali, C.C.; Fanaee-Danesh, E.; Zandl-Lang, M.; Albrecher, N.M.; Tam-Amersdorfer, C.; Stracke, A.; Sachdev, V.; Reichmann, F.; Sun, Y.; Avdili, A. Amyloid-Beta Impairs Insulin Signaling by Accelerating Autophagy-Lysosomal Degradation of LRP-1 and IR- $\beta$ in Blood-Brain Barrier Endothelial Cells in Vitro and in 3XTg-AD Mice. Mol. Cell. Neurosci. 2019, 99, 103390. [CrossRef]

138. Huang, Z.; Wong, L.-W.; Su, Y.; Huang, X.; Wang, N.; Chen, H.; Yi, C. Blood-Brain Barrier Integrity in the Pathogenesis of Alzheimer's Disease. Front. Neuroendocrinol. 2020, 59, 100857. [CrossRef]

139. Kovac, A.; Zilkova, M.; Deli, M.A.; Zilka, N.; Novak, M. Human Truncated Tau Is Using a Different Mechanism from Amyloid- $\beta$ to Damage the Blood-Brain Barrier. J. Alzheimer's Dis. 2009, 18, 897-906. [CrossRef]

140. Michalicova, A.; Majerova, P.; Kovac, A. Tau Protein and Its Role in Blood-Brain Barrier Dysfunction. Front. Mol. Neurosci. 2020, 13, 178. [CrossRef] [PubMed]

141. Dickson, D.W.; Lee, S.C.; Mattiace, L.A.; Yen, S.C.; Brosnan, C. Microglia and Cytokines in Neurological Disease, with Special Reference to AIDS and Alzheimer's Disease. Glia 1993, 7, 75-83. [CrossRef] [PubMed]

142. Sciacca, F.L.; Ferri, C.; Licastro, F.; Veglia, F.; Biunno, I.; Gavazzi, A.; Calabrese, E.; Boneschi, F.M.; Sorbi, S.; Mariani, C. Interleukin-1B Polymorphism Is Associated with Age at Onset of Alzheimer's Disease. Neurobiol. Aging 2003, 24, 927-931. [CrossRef]

143. Letiembre, M.; Liu, Y.; Walter, S.; Hao, W.; Pfander, T.; Wrede, A.; Schulz-Schaeffer, W.; Fassbender, K. Screening of Innate Immune Receptors in Neurodegenerative Diseases: A Similar Pattern. Neurobiol. Aging 2009, 30, 759-768. [CrossRef]

144. Kitazawa, M.; Cheng, D.; Tsukamoto, M.R.; Koike, M.A.; Wes, P.D.; Vasilevko, V.; Cribbs, D.H.; LaFerla, F.M. Blocking IL-1 Signaling Rescues Cognition, Attenuates Tau Pathology, and Restores Neuronal $\beta$-Catenin Pathway Function in an Alzheimer's Disease Model. J. Immunol. 2011, 187, 6539-6549. [CrossRef] [PubMed]

145. Eikelenboom, P.; van Exel, E.; Veerhuis, R.; Rozemuller, A.J.M.; van Gool, W.A.; Hoozemans, J.J.M. Innate Immunity and the Etiology of Late-Onset Alzheimer's Disease. Neurodegener. Dis. 2012, 10, 271-273. [CrossRef]

146. Heneka, M.T.; McManus, R.M.; Latz, E. Inflammasome Signalling in Brain Function and Neurodegenerative Disease. Nat. Rev. Neurosci. 2018, 19, 610-621. [CrossRef] [PubMed]

147. Brosseron, F.; Krauthausen, M.; Kummer, M.; Heneka, M.T. Body Fluid Cytokine Levels in Mild Cognitive Impairment and Alzheimer's Disease: A Comparative Overview. Mol. Neurobiol. 2014, 50, 534-544. [CrossRef] [PubMed]

148. Licastro, F.; Pedrini, S.; Caputo, L.; Annoni, G.; Davis, L.J.; Ferri, C.; Casadei, V.; Grimaldi, L.M.E. Increased Plasma Levels of Interleukin-1, Interleukin-6 and $\alpha$-1-Antichymotrypsin in Patients with Alzheimer's Disease: Peripheral Inflammation or Signals from the Brain? J. Neuroimmunol. 2000, 103, 97-102. [CrossRef]

149. Engelhart, M.J.; Geerlings, M.I.; Meijer, J.; Kiliaan, A.; Ruitenberg, A.; van Swieten, J.C.; Stijnen, T.; Hofman, A.; Witteman, J.C.M.; Breteler, M.M.B. Inflammatory Proteins in Plasma and the Risk of Dementia: The Rotterdam Study. Arch. Neurol. 2004, 61, 668-672. [CrossRef]

150. Tilvis, R.S.; Kähönen-Väre, M.H.; Jolkkonen, J.; Valvanne, J.; Pitkala, K.H.; Strandberg, T.E. Predictors of Cognitive Decline and Mortality of Aged People over a 10-Year Period. J. Gerontol. Ser. A Biol. Sci. Med. Sci. 2004, 59, M268-M274. [CrossRef]

151. MERAZ RIOS, M.A.; Toral-Rios, D.; Franco-Bocanegra, D.; Villeda-Hernández, J.; Campos-Peña, V. Inflammatory Process in Alzheimer's Disease. Front. Integr. Neurosci. 2013, 7, 59. [CrossRef]

152. Louveau, A.; Harris, T.H.; Kipnis, J. Revisiting the Mechanisms of CNS Immune Privilege. Trends Immunol. 2015, 36, 569-577. [CrossRef]

153. Takeda, S.; Sato, N.; Morishita, R. Systemic Inflammation, Blood-Brain Barrier Vulnerability and Cognitive/Non-Cognitive Symptoms in Alzheimer Disease: Relevance to Pathogenesis and Therapy. Front. Aging Neurosci. 2014, 6, 171. [CrossRef]

154. Varatharaj, A.; Galea, I. The Blood-Brain Barrier in Systemic Inflammation. Brain Behav. Immun. 2017, 60, 1-12. [CrossRef]

155. Zenaro, E.; Piacentino, G.; Constantin, G. The Blood-Brain Barrier in Alzheimer's Disease. Neurobiol. Dis. 2017, 107, 41-56. [CrossRef]

156. Elwood, E.; Lim, Z.; Naveed, H.; Galea, I. The Effect of Systemic Inflammation on Human Brain Barrier Function. Brain Behav. Immun. 2017, 62, 35-40. [CrossRef]

157. Wichmann, M.A.; Cruickshanks, K.J.; Carlsson, C.M.; Chappell, R.; Fischer, M.E.; Klein, B.E.K.; Klein, R.; Tsai, M.Y.; Schubert, C.R. Long-term Systemic Inflammation and Cognitive Impairment in a Population-based Cohort. J. Am. Geriatr. Soc. 2014, 62, 1683-1691. [CrossRef] [PubMed]

158. Chakrabarti, S.; Khemka, V.K.; Banerjee, A.; Chatterjee, G.; Ganguly, A.; Biswas, A. Metabolic Risk Factors of Sporadic Alzheimer's Disease: Implications in the Pathology, Pathogenesis and Treatment. Aging Dis. 2015, 6, 282. [CrossRef] [PubMed] 
159. Moreno-Gonzalez, I.; Edwards, G., III; Salvadores, N.; Shahnawaz, M.; Diaz-Espinoza, R.; Soto, C. Molecular Interaction between Type 2 Diabetes and Alzheimer's Disease through Cross-Seeding of Protein Misfolding. Mol. Psychiatry 2017, 22, 1327-1334. [CrossRef] [PubMed]

160. Edwards, G.A., III; Gamez, N.; Escobedo, G., Jr.; Calderon, O.; Moreno-Gonzalez, I. Modifiable Risk Factors for Alzheimer's Disease. Front. Aging Neurosci. 2019, 11, 146. [CrossRef] [PubMed]

161. Amor, S.; Peferoen, L.A.N.; Vogel, D.Y.S.; Breur, M.; van der Valk, P.; Baker, D.; van Noort, J.M. Inflammation in Neurodegenerative Diseases-an Update. Immunology 2014, 142, 151-166. [CrossRef] [PubMed]

162. Ferreira, S.T.; Clarke, J.R.; Bomfim, T.R.; de Felice, F.G. Inflammation, Defective Insulin Signaling, and Neuronal Dysfunction in Alzheimer's Disease. Alzheimer's Dement. 2014, 10, S76-S83. [CrossRef]

163. Odegaard, J.I.; Chawla, A. Pleiotropic Actions of Insulin Resistance and Inflammation in Metabolic Homeostasis. Science 2013, 339, 172-177. [CrossRef]

164. Ouchi, N.; Parker, J.L.; Lugus, J.J.; Walsh, K. Adipokines in Inflammation and Metabolic Disease. Nat. Rev. Immunol. 2011, 11, 85-97. [CrossRef]

165. Parimisetty, A.; Dorsemans, A.-C.; Awada, R.; Ravanan, P.; Diotel, N.; d’Hellencourt, C.L. Secret Talk between Adipose Tissue and Central Nervous System via Secreted Factors-an Emerging Frontier in the Neurodegenerative Research. J. Neuroinflamm. 2016, 13, 1-13. [CrossRef]

166. Martini, S.R.; Kent, T.A. Hyperglycemia in Acute Ischemic Stroke: A Vascular Perspective. J. Cereb. Blood Flow Metab. 2007, 27, 435-451. [CrossRef]

167. Lohmann, C.; Schäfer, N.; von Lukowicz, T.; Stein, M.A.S.; Borén, J.; Rütti, S.; Wahli, W.; Donath, M.Y.; Lüscher, T.F.; Matter, C.M. Atherosclerotic Mice Exhibit Systemic Inflammation in Periadventitial and Visceral Adipose Tissue, Liver, and Pancreatic Islets. Atherosclerosis 2009, 207, 360-367. [CrossRef]

168. Gustafson, D.R.; Karlsson, C.; Skoog, I.; Rosengren, L.; Lissner, L.; Blennow, K. Mid-life Adiposity Factors Relate to Blood-Brain Barrier Integrity in Late Life. J. Intern. Med. 2007, 262, 643-650. [CrossRef]

169. Prasad, S.; Sajja, R.K.; Naik, P.; Cucullo, L. Diabetes Mellitus and Blood-Brain Barrier Dysfunction: An Overview. J. Pharmacovigil. 2014, 2, 125.

170. de Oliveira, J.; Moreira, E.L.G.; dos Santos, D.B.; Piermartiri, T.C.; Dutra, R.C.; Pinton, S.; Tasca, C.I.; Farina, M.; Prediger, R.D.S.; de Bem, A.F. Increased Susceptibility to Amyloid- $\beta$-Induced Neurotoxicity in Mice Lacking the Low-Density Lipoprotein Receptor. J. Alzheimer's Dis. 2014, 41, 43-60. [CrossRef] [PubMed]

171. de Oliveira, J.; Engel, D.F.; de Paula, G.C.; dos Santos, D.B.; Lopes, J.B.; Farina, M.; Moreira, E.L.G.; de Bem, A.F. High Cholesterol Diet Exacerbates Blood-Brain Barrier Disruption in LDLr-/-Mice: Impact on Cognitive Function. J. Alzheimer's Dis. 2020, 1-19. [CrossRef] [PubMed]

172. Streit, W.J.; Sparks, D.L. Activation of Microglia in the Brains of Humans with Heart Disease and Hypercholesterolemic Rabbits. J. Mol. Med. 1997, 75, 130-138. [CrossRef] [PubMed]

173. Sparks, D.L.; KUO, Y.; Roher, A.; Martin, T.; Lukas, R.J. Alterations of Alzheimer's Disease in the Cholesterol-fed Rabbit, Including Vascular Inflammation: Preliminary Observations. Ann. N. Y. Acad. Sci. 2000, 903, 335-344. [CrossRef] [PubMed]

174. Prasanthi, R.P.J.; Schommer, E.; Thomasson, S.; Thompson, A.; Feist, G.; Ghribi, O. Regulation of $\beta$-Amyloid Levels in the Brain of Cholesterol-Fed Rabbit, a Model System for Sporadic Alzheimer's Disease. Mech. Ageing Dev. 2008, 129, 649-655. [CrossRef] [PubMed]

175. Thirumangalakudi, L.; Prakasam, A.; Zhang, R.; Bimonte-Nelson, H.; Sambamurti, K.; Kindy, M.S.; Bhat, N.R. High Cholesterolinduced Neuroinflammation and Amyloid Precursor Protein Processing Correlate with Loss of Working Memory in Mice. J. Neurochem. 2008, 106, 475-485. [CrossRef] [PubMed]

176. Zlokovic, B.V. Clearing Amyloid through the Blood-Brain Barrier. J. Neurochem. 2004, 89, 807-811. [CrossRef]

177. Desale, S.E.; Chinnathambi, S. Role of Dietary Fatty Acids in Microglial Polarization in Alzheimer's Disease. J. Neuroinflamm. 2020, 17, 1-14. [CrossRef] [PubMed]

178. Jacob, A.; Brorson, J.R.; Alexander, J.J. Septic Encephalopathy: Inflammation in Man and Mouse. Neurochem. Int. 2011, 58, 472-476. [CrossRef]

179. Dal-Pizzol, F.; Tomasi, C.D.; Ritter, C. Septic Encephalopathy: Does Inflammation Drive the Brain Crazy? Braz. J. Psychiatry 2014, 36, 251-258. [CrossRef]

180. Barichello, T.; Generoso, J.S.; Goularte, J.A.; Collodel, A.; Pitcher, M.R.; Simões, L.R.; Quevedo, J.; Dal-Pizzol, F. Does InfectionInduced Immune Activation Contribute to Dementia? Aging Dis. 2015, 6, 342. [CrossRef]

181. Giridharan, V.V.; Masud, F.; Petronilho, F.; Dal-Pizzol, F.; Barichello, T. Infection-Induced Systemic Inflammation Is a Potential Driver of Alzheimer's Disease Progression. Front. Aging Neurosci. 2019, 11, 122. [CrossRef]

182. Gasparotto, J.; Girardi, C.S.; Somensi, N.; Ribeiro, C.T.; Moreira, J.C.F.; Michels, M.; Sonai, B.; Rocha, M.; Steckert, A.V.; Barichello, T. Receptor for Advanced Glycation End Products Mediates Sepsis-Triggered Amyloid- $\beta$ Accumulation, Tau Phosphorylation, and Cognitive Impairment. J. Biol. Chem. 2018, 293, 226-244. [CrossRef]

183. de Felice, F.G.; Tovar-Moll, F.; Moll, J.; Munoz, D.P.; Ferreira, S.T. Severe Acute Respiratory Syndrome Coronavirus 2 (SARS-CoV-2) and the Central Nervous System. Trends Neurosci. 2020, 43, 355-357. [CrossRef] [PubMed]

184. Li, Y.; Bai, W.; Hashikawa, T. The Neuroinvasive Potential of SARS-CoV2 May Play a Role in the Respiratory Failure of COVID-19 Patients. J. Med. Virol. 2020, 92, 552-555. [CrossRef] [PubMed] 
185. Mao, L.; Jin, H.; Wang, M.; Hu, Y.; Chen, S.; He, Q.; Chang, J.; Hong, C.; Zhou, Y.; Wang, D. Neurologic Manifestations of Hospitalized Patients with Coronavirus Disease 2019 in Wuhan, China. JAMA Neurol. 2020, 77, 683-690. [CrossRef] [PubMed]

186. Ellul, M.A.; Benjamin, L.; Singh, B.; Lant, S.; Michael, B.D.; Easton, A.; Kneen, R.; Defres, S.; Sejvar, J.; Solomon, T. Neurological Associations of COVID-19. Lancet Neurol. 2020, 19, 767-783. [CrossRef]

187. Heneka, M.T.; Golenbock, D.; Latz, E.; Morgan, D.; Brown, R. Immediate and Long-Term Consequences of COVID-19 Infections for the Development of Neurological Disease. Alzheimer's Res. Ther. 2020, 12, 1-3. [CrossRef] [PubMed]

188. Fotuhi, M.; Mian, A.; Meysami, S.; Raji, C.A. Neurobiology of COVID-19. J. Alzheimer's Dis. 2020, 76, 3-19. [CrossRef]

189. Wang, Y.; Ding, L.; Zhu, Q.; Shu, M.; Cai, Q. Common Infections May Lead to Alzheimer's Disease. Virol. Sin. 2018, 33, 456-458. [CrossRef]

190. Sochocka, M.; Zwolinska, K.; Leszek, J. The Infectious Etiology of Alzheimer's Disease. Curr. Neuropharmacol. 2017, 15, 996-1009. [CrossRef]

191. Van Giau, V.; Wu, S.Y.; Jamerlan, A.; An, S.S.A.; Kim, S.; Hulme, J. Gut Microbiota and Their Neuroinflammatory Implications in Alzheimer's Disease. Nutrients 2018, 10, 1765. [CrossRef]

192. Morris, G.; Berk, M.; Maes, M.; Puri, B.K. Could Alzheimer's Disease Originate in the Periphery and If so How so? Mol. Neurobiol. 2019, 56, 406-434. [CrossRef]

193. Belkaid, Y.; Hand, T.W. Role of the Microbiota in Immunity and Inflammation. Cell 2014, 157, 121-141. [CrossRef]

194. Wen, L.; Duffy, A. Factors Influencing the Gut Microbiota, Inflammation, and Type 2 Diabetes. J. Nutr. 2017, 147, 1468S-1475S. [CrossRef]

195. Rothhammer, V.; Borucki, D.M.; Tjon, E.C.; Takenaka, M.C.; Chao, C.-C.; Ardura-Fabregat, A.; de Lima, K.A.; Gutiérrez-Vázquez, C.; Hewson, P.; Staszewski, O. Microglial Control of Astrocytes in Response to Microbial Metabolites. Nature 2018, 557, 724-728. [CrossRef]

196. Sochocka, M.; Donskow-Łysoniewska, K.; Diniz, B.S.; Kurpas, D.; Brzozowska, E.; Leszek, J. The Gut Microbiome Alterations and Inflammation-Driven Pathogenesis of Alzheimer's Disease-A Critical Review. Mol. Neurobiol. 2019, 56, 1841-1851. [CrossRef]

197. Dominy, S.S.; Lynch, C.; Ermini, F.; Benedyk, M.; Marczyk, A.; Konradi, A.; Nguyen, M.; Haditsch, U.; Raha, D.; Griffin, C. Porphyromonas Gingivalis in Alzheimer's Disease Brains: Evidence for Disease Causation and Treatment with Small-Molecule Inhibitors. Sci. Adv. 2019, 5, eaau3333. [CrossRef]

198. Beydoun, M.A.; Beydoun, H.A.; Hossain, S.; El-Hajj, Z.W.; Weiss, J.; Zonderman, A.B. Clinical and Bacterial Markers of Periodontitis and Their Association with Incident All-Cause and Alzheimer's Disease Dementia in a Large National Survey. J. Alzheimer's Dis. 2020, 75, 157-172. [CrossRef] [PubMed]

199. Li, X.; Kolltveit, K.M.; Tronstad, L.; Olsen, I. Systemic Diseases Caused by Oral Infection. Clin. Microbiol. Rev. 2000, 13, 547-558. [CrossRef] [PubMed]

200. Jiang, M.; Zhang, X.; Yan, X.; Mizutani, S.; Kashiwazaki, H.; Ni, J.; Wu, Z. GSK3 $\beta$ Is Involved in Promoting Alzheimer's Disease Pathologies Following Chronic Systemic Exposure to Porphyromonas Gingivalis Lipopolysaccharide in Amyloid Precursor ProteinNL-F/NL-F Knock-in Mice. Brain Behav. Immun. 2021, 98, 1-12. [CrossRef] [PubMed]

201. Casey, D.A.; Antimisiaris, D.; O’Brien, J. Drugs for Alzheimer's Disease: Are They Effective? Pharm. Ther. 2010, $35,208$.

202. Martyn, C. Anti-Inflammatory Drugs and Alzheimer's Disease. BMJ 2003, 327, 353. [CrossRef]

203. Breitner, J.C.S.; Gau, B.A.; Welsh, K.A.; Plassman, B.L.; McDonald, W.M.; Helms, M.J.; Anthony, J.C. Inverse Association of Anti-inflammatory Treatments and Alzheimer's Disease: Initial Results of a Co-twin Control Study. Neurology 1994, $44,227$. [CrossRef] [PubMed]

204. Breitner, J.C.; Baker, L.D.; Montine, T.J.; Meinert, C.L.; Lyketsos, C.G.; Ashe, K.H.; Brandt, J.; Craft, S.; Evans, D.E.; Green, R.C. Extended Results of the Alzheimer's Disease Anti-Inflammatory Prevention Trial. Alzheimer's Dement. 2011, 7, 402-411. [CrossRef] [PubMed]

205. Andersen, K.; Launer, L.J.; Ott, A.; Hoes, A.W.; Breteler, M.M.B.; Hofman, A. Do Nonsteroidal Anti-Inflammatory Drugs Decrease the Risk for Alzheimer's Disease?: The Rotterdam Study. Neurology 1995, 45, 1441-1445. [CrossRef] [PubMed]

206. Gasparini, L.; Ongini, E.; Wenk, G. Non-steroidal Anti-inflammatory Drugs (NSAIDs) in Alzheimer's Disease: Old and New Mechanisms of Action. J. Neurochem. 2004, 91, 521-536. [CrossRef]

207. Shadfar, S.; Hwang, C.J.; Lim, M.-S.; Choi, D.-Y.; Hong, J.T. Involvement of Inflammation in Alzheimer's Disease Pathogenesis and Therapeutic Potential of Anti-Inflammatory Agents. Arch. Pharmacal Res. 2015, 38, 2106-2119. [CrossRef]

208. McGeer, P.L.; Guo, J.P.; Lee, M.; Kennedy, K.; McGeer, E.G. Alzheimer's Disease Can Be Spared by Nonsteroidal Anti-Inflammatory Drugs. J. Alzheimer's Dis. 2018, 62, 1219-1222. [CrossRef]

209. Sastre, M.; Dewachter, I.; Landreth, G.E.; Willson, T.M.; Klockgether, T.; van Leuven, F.; Heneka, M.T. Nonsteroidal AntiInflammatory Drugs and Peroxisome Proliferator-Activated Receptor- $\gamma$ Agonists Modulate Immunostimulated Processing of Amyloid Precursor Protein through Regulation of $\beta$-Secretase. J. Neurosci. 2003, 23, 9796-9804. [CrossRef]

210. Sastre, M.; Dewachter, I.; Rossner, S.; Bogdanovic, N.; Rosen, E.; Borghgraef, P.; Evert, B.O.; Dumitrescu-Ozimek, L.; Thal, D.R.; Landreth, G. Nonsteroidal Anti-Inflammatory Drugs Repress $\beta$-Secretase Gene Promoter Activity by the Activation of PPAR $\gamma$. Proc. Natl. Acad. Sci. USA 2006, 103, 443-448. [CrossRef]

211. Eriksen, J.L.; Sagi, S.A.; Smith, T.E.; Weggen, S.; Das, P.; McLendon, D.C.; Ozols, V.V.; Jessing, K.W.; Zavitz, K.H.; Koo, E.H. NSAIDs and Enantiomers of Flurbiprofen Target $\gamma$-Secretase and Lower A $\beta 42$ in Vivo. J. Clin. Investig. 2003, 112, 440-449. [CrossRef] [PubMed] 
212. Sung, S.; Yang, H.; Uryu, K.; Lee, E.B.; Zhao, L.; Shineman, D.; Trojanowski, J.Q.; Lee, V.M.-Y.; Praticò, D. Modulation of Nuclear Factor-KB Activity by Indomethacin Influences A $\beta$ Levels but Not A $\beta$ Precursor Protein Metabolism in a Model of Alzheimer's Disease. Am. J. Pathol. 2004, 165, 2197-2206. [CrossRef]

213. Heneka, M.T.; Sastre, M.; Dumitrescu-Ozimek, L.; Hanke, A.; Dewachter, I.; Kuiperi, C.; O'Banion, K.; Klockgether, T.; van Leuven, F.; Landreth, G.E. Acute Treatment with the PPAR $\gamma$ Agonist Pioglitazone and Ibuprofen Reduces Glial Inflammation and A $31-42$ Levels in APPV717I Transgenic Mice. Brain 2005, 128, 1442-1453. [CrossRef]

214. Medeiros, R.; Kitazawa, M.; Passos, G.F.; Baglietto-Vargas, D.; Cheng, D.; Cribbs, D.H.; LaFerla, F.M. Aspirin-Triggered Lipoxin A4 Stimulates Alternative Activation of Microglia and Reduces Alzheimer Disease-Like Pathology in Mice. Am. J. Pathol. 2013, 182, 1780-1789. [CrossRef] [PubMed]

215. Jaturapatporn, D.; Isaac, M.G.E.K.N.; McCleery, J.; Tabet, N. Aspirin, Steroidal and Non-steroidal Anti-inflammatory Drugs for the Treatment of Alzheimer's Disease. Cochrane Database Syst. Rev. 2012. [CrossRef]

216. Lichtenstein, M.P.; Carriba, P.; Masgrau, R.; Pujol, A.; Galea, E. Staging Anti-Inflammatory Therapy in Alzheimer's Disease. Front. Aging Neurosci. 2010, 2, 142. [CrossRef]

217. Dhouafli, Z.; Cuanalo-Contreras, K.; Hayouni, E.A.; Mays, C.E.; Soto, C.; Moreno-Gonzalez, I. Inhibition of Protein Misfolding and Aggregation by Natural Phenolic Compounds. Cell. Mol. Life Sci. 2018, 75, 3521-3538. [CrossRef] [PubMed]

218. Habtemariam, S. Natural Products in Alzheimer's Disease Therapy: Would Old Therapeutic Approaches Fix the Broken Promise of Modern Medicines? Molecules 2019, 24, 1519. [CrossRef] [PubMed]

219. Rosales-Corral, S.; Tan, D.; Reiter, R.J.; Valdivia-Velázquez, M.; Martínez-Barboza, G.; Pablo Acosta-Martínez, J.; Ortiz, G.G. Orally Administered Melatonin Reduces Oxidative Stress and Proinflammatory Cytokines Induced by Amyloid- $\beta$ Peptide in Rat Brain: A Comparative, in Vivo Study versus Vitamin C and E. J. Pineal Res. 2003, 35, 80-84. [CrossRef] [PubMed]

220. Yu, J.; Gattoni-Celli, M.; Zhu, H.; Bhat, N.R.; Sambamurti, K.; Gattoni-Celli, S.; Kindy, M.S. Vitamin D 3-Enriched Diet Correlates with a Decrease of Amyloid Plaques in the Brain of AßPP Transgenic Mice. J. Alzheimer's Dis. 2011, 25, 295-307. [CrossRef]

221. Zhao, H.F.; Li, N.; Wang, Q.; Cheng, X.J.; Li, X.M.; Liu, T.T. Resveratrol Decreases the Insoluble A $\beta 1-42$ Level in Hippocampus and Protects the Integrity of the Blood-Brain Barrier in AD Rats. Neuroscience 2015, 310, 641-649. [CrossRef]

222. Grimm, M.O.W.; Thiel, A.; Lauer, A.A.; Winkler, J.; Lehmann, J.; Regner, L.; Nelke, C.; Janitschke, D.; Benoist, C.; Streidenberger, O. Vitamin D and Its Analogues Decrease Amyloid- $\beta$ (A $\beta$ ) Formation and Increase A $\beta$-Degradation. Int. J. Mol. Sci. 2017, $18,2764$. [CrossRef]

223. Andrade, S.; Ramalho, M.J.; Loureiro, J.A.; Pereira, M. do C. Natural Compounds for Alzheimer's Disease Therapy: A Systematic Review of Preclinical and Clinical Studies. Int. J. Mol. Sci. 2019, 20, 2313. [CrossRef]

224. Cederholm, T.; Salem, N., Jr.; Palmblad, J. w-3 Fatty Acids in the Prevention of Cognitive Decline in Humans. Adv. Nutr. 2013, 4, 672-676. [CrossRef]

225. Hjorth, E.; Zhu, M.; Toro, V.C.; Vedin, I.; Palmblad, J.; Cederholm, T.; Freund-Levi, Y.; Faxen-Irving, G.; Wahlund, L.-O.; Basun, H. Omega-3 Fatty Acids Enhance Phagocytosis of Alzheimer's Disease-Related Amyloid- $\beta 42$ by Human Microglia and Decrease Inflammatory Markers. J. Alzheimer's Dis. 2013, 35, 697-713. [CrossRef]

226. della Giustina, A.; de Souza Goldim, M.P.; Danielski, L.G.; Garbossa, L.; Junior, A.N.O.; Cidreira, T.; Denicol, T.; Bonfante, S.; da Rosa, N.; Fortunato, J.J. Lipoic Acid and Fish Oil Combination Potentiates Neuroinflammation and Oxidative Stress Regulation and Prevents Cognitive Decline of Rats After Sepsis. Mol. Neurobiol. 2020, 57, 4451-4466. [CrossRef]

227. Lawlor, B.; Segurado, R.; Kennelly, S.; Olde Rikkert, M.G.M.; Howard, R.; Pasquier, F.; Börjesson-Hanson, A.; Tsolaki, M.; Lucca, U.; Molloy, D.W. Nilvadipine in Mild to Moderate Alzheimer Disease: A Randomised Controlled Trial. PLoS Med. 2018, 15, e1002660. [CrossRef]

228. Meyer, P.-F.; Tremblay-Mercier, J.; Leoutsakos, J.; Madjar, C.; Lafaille-Maignan, M.-É.; Savard, M.; Rosa-Neto, P.; Poirier, J.; Etienne, P.; Breitner, J. INTREPAD: A Randomized Trial of Naproxen to Slow Progress of Presymptomatic Alzheimer Disease. Neurology 2019, 92, e2070-e2080. [CrossRef] [PubMed]

229. Howard, R.; Zubko, O.; Bradley, R.; Harper, E.; Pank, L.; O’brien, J.; Fox, C.; Tabet, N.; Livingston, G.; Bentham, P. Minocycline at 2 Different Dosages vs Placebo for Patients with Mild Alzheimer Disease: A Randomized Clinical Trial. JAMA Neurol. 2020, 77, 164-174. [CrossRef]

230. Ryan, J.; Storey, E.; Murray, A.M.; Woods, R.L.; Wolfe, R.; Reid, C.M.; Nelson, M.R.; Chong, T.T.J.; Williamson, J.D.; Ward, S.A. Randomized Placebo-Controlled Trial of the Effects of Aspirin on Dementia and Cognitive Decline. Neurology 2020, 95, e320-e331. [CrossRef] [PubMed]

231. Muller, A.P.; Ferreira, G.K.; Pires, A.J.; de Bem Silveira, G.; de Souza, D.L.; de Abreu Brandolfi, J.; de Souza, C.T.; Paula, M.M.S.; Silveira, P.C.L. Gold Nanoparticles Prevent Cognitive Deficits, Oxidative Stress and Inflammation in a Rat Model of Sporadic Dementia of Alzheimer's Type. Mater. Sci. Eng. C 2017, 77, 476-483. [CrossRef] [PubMed]

232. Sanati, M.; Khodagholi, F.; Aminyavari, S.; Ghasemi, F.; Gholami, M.; Kebriaeezadeh, A.; Sabzevari, O.; Hajipour, M.J.; Imani, M.; Mahmoudi, M. Impact of Gold Nanoparticles on Amyloid $\beta$-Induced Alzheimer's Disease in a Rat Animal Model: Involvement of STIM Proteins. ACS Chem. Neurosci. 2019, 10, 2299-2309. [CrossRef]

233. Rodrigues, M.S.; de Paula, G.C.; Duarte, M.B.; de Rezende, V.L.; Possato, J.C.; Farias, H.R.; Medeiros, E.B.; Feuser, P.E.; Streck, E.L.; de Ávila, R.A.M. Nanotechnology as a Therapeutic Strategy to Prevent Neuropsychomotor Alterations Associated with Hypercholesterolemia. Colloids Surf. B Biointerfaces 2021, 201, 111608. [CrossRef] [PubMed] 